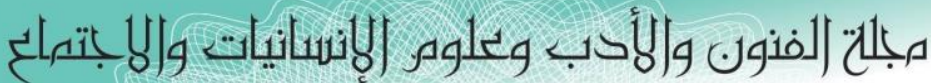

Journal of Arts, Literature, Humanities and Social Sciences

ISSN online: 2414 - 3383

ISSN print: 2616 - 3810

العدد (41) آب - أغسطس 2019

\title{
التحكيم في تسوية منازعات العقود النفطية
}

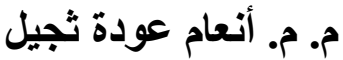

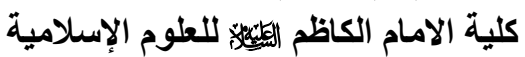 \\ العراق العاق
}

الماخص

عرف التحكيم عبر التاريخ كوسيلة لفض المنازعات الفردية والجماعية في نطاق المعاملات التجارية و الدولية الا انه في الفترة الاخيرة وفي ظل النظام العالمي الجديد اكتسب اهمية بالغة خصوصا في ظل التقدم العلمي في وسائل الاتصال وحجم المبادلات بين الدول لما يمتاز به من سهولة في اجر اءاته وتحرره من القيود و التعقيدات الموجودة في النظم الاخرى اضافة إلى تجاوبه إلى منطلبات التعاملات الدولية وقد ارتبط التحكيم بفكرة التنمية الاقتصادية وجذب الاستثمار ات الاجنبية وخصوصا في مجال الاستثمارات النفطية التي تحتل اهمية سياسية و اقتصادية وتجارية فهو المعدن الاستر اتيجي ويعود اليه الفضل في التقدم الذي احرزه الانسان في نواحي الحياة المختلفة لهذا حرص في اغلب العقود النفطية على تضمين شرط التحكيم كوسيلة لحل المناز عات التي ممكن ان تتشأ بين الطرفين مستقبلا وذلك لما له من مميزات تجعل افضل من الوسائل الاخرى من حيث السرعة في انجازه و السرية التي تستوجبها العقود النفطية وكفاءة المحكمين نظر الطبيعة هذه العقود التي تحتاج إلى خبرات فنية دقيقة قد لانو اجد في الوسائل الاخرى. 


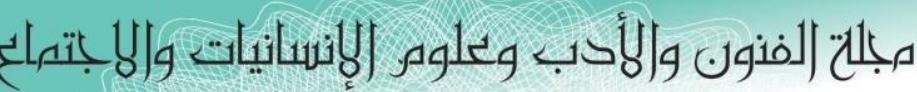

Journal of Arts, Literature, Humanities and Social Sciences

ISSN online: 2414 - 3383

ISSN print: 2616 - 3810

العدد (41) آب - أغلسطلس 2019

\title{
Arbitration In Settling Disputes Of Oil Contracts
}

\author{
Aneam Aoda Thajil \\ Imam Kadhim College of Islamic Sciences \\ Iraq
}

\begin{abstract}
Historically, arbitration has been known as a means of resolving individual and collective disputes in the scope of international and commercial transactions. However, in the recent period, under the new world order, it has become very important, especially in light of the scientific progress in the means of communication and the volume of exchanges among States. In addition to its response to the requirements of international transactions. The arbitration was linked to the idea of economic development and attract foreign investment, especially in the field of oil investments, which occupies political, economic and commercial importance, it is the strategic metal This is due to the progress made by man in various aspects of life. This is keen in most oil contracts to include arbitration clause as a means of resolving disputes that may arise between the two parties in the future because of its advantages make better than other means in terms of speed in the completion and confidentiality required by Oil contracts and the efficiency of arbitrators in view of the nature of these contracts, which require accurate technical expertise may not exist in other means.
\end{abstract}




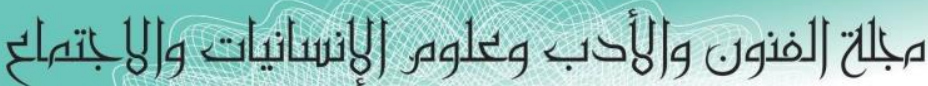

Journal of Arts, Literature, Humanities and Social Sciences

ISSN online: 2414 - 3383

ISSN print: 2616 - 3810

\section{العدد (41) آب - أغسطس 2019}

CALHSS

www.jalhss.com

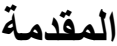

أولاً: موضوعة البحث البمث

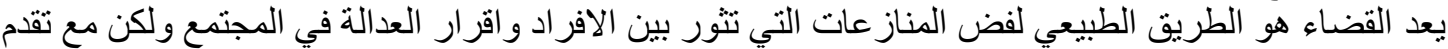

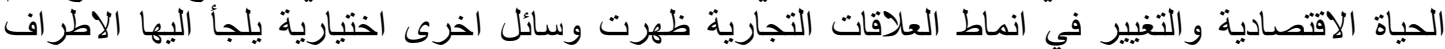

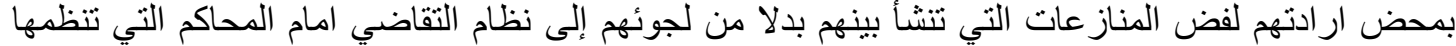

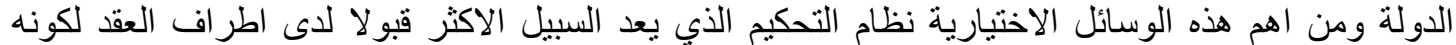

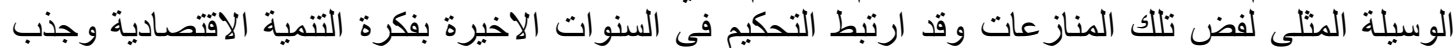

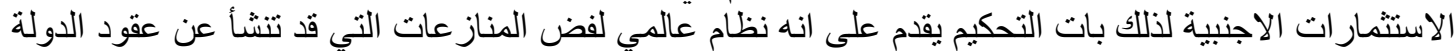

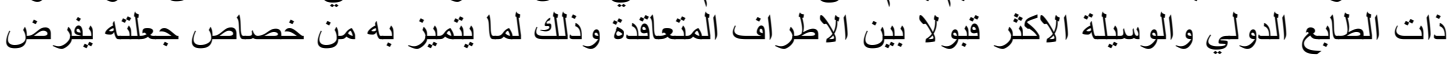

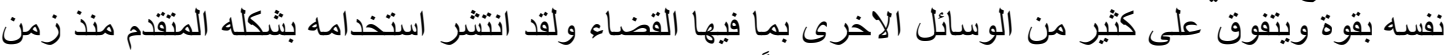

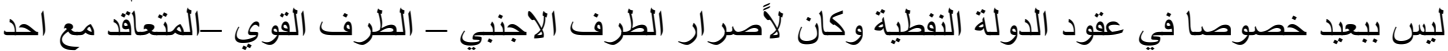

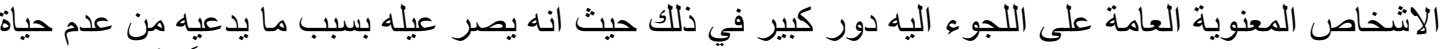

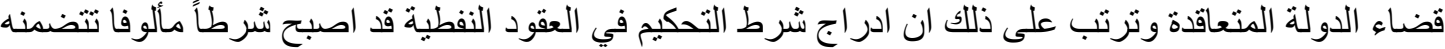

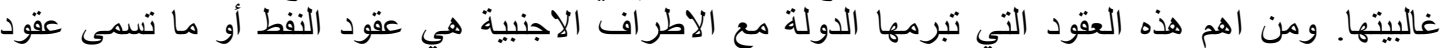

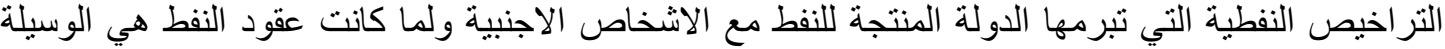

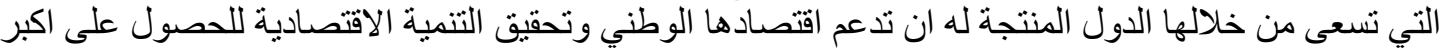

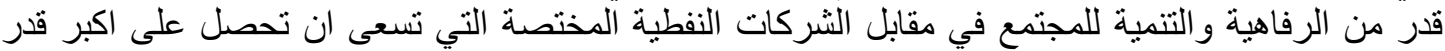

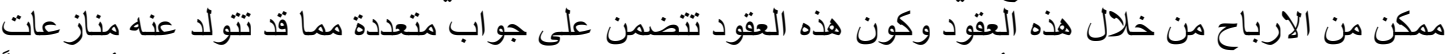

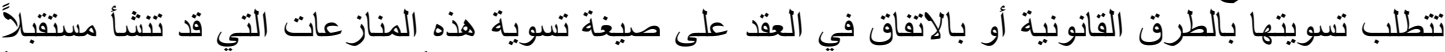

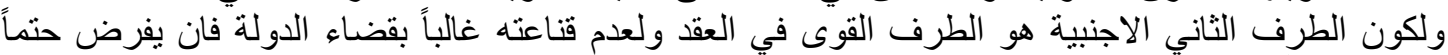

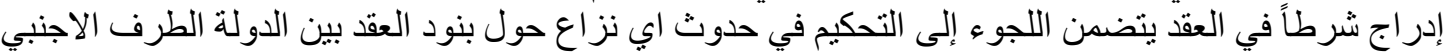

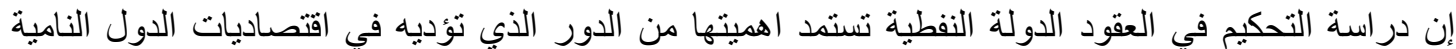

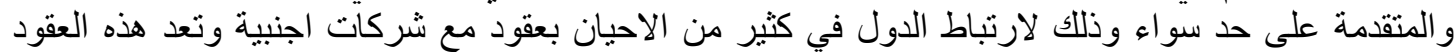

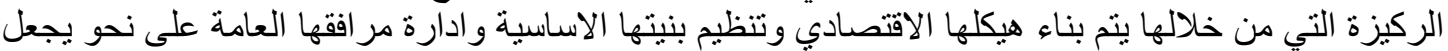

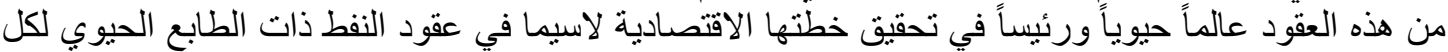

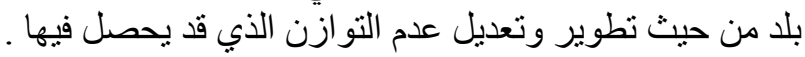

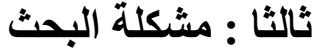

بما ان موضوع البحث ينصب على عقود ادارية دولية وان اطر افه ليس في مركز قانوني متساوي حيث ينتمي

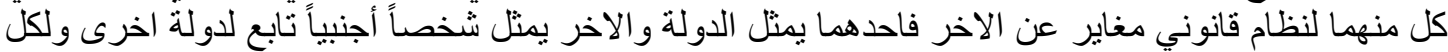

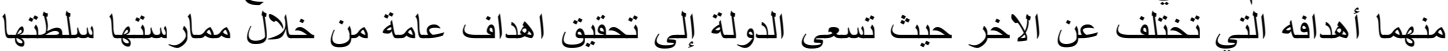

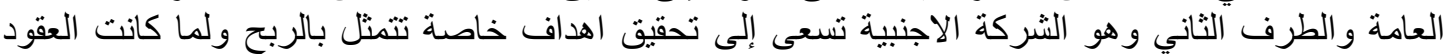

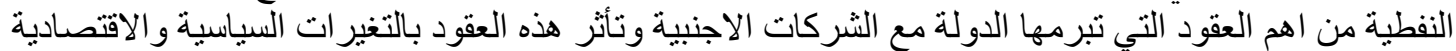

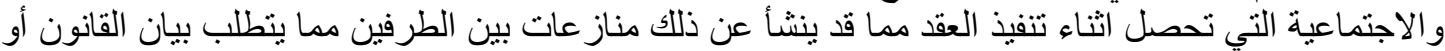

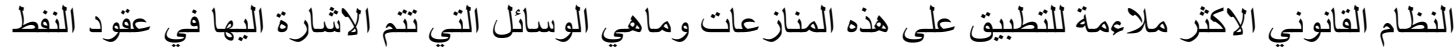

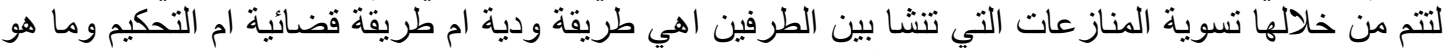

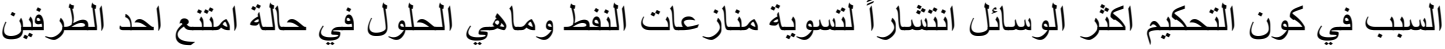

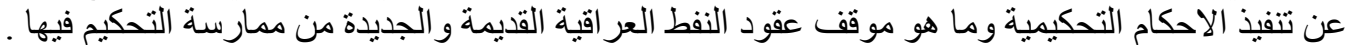

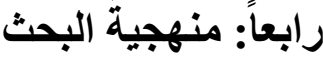
سوف نعتمد في در اسة البحث على المنهاج التحليلي الوصفي للنصوص و التشريعات والاتفاقيات المعتمدة بهذا

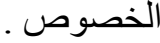




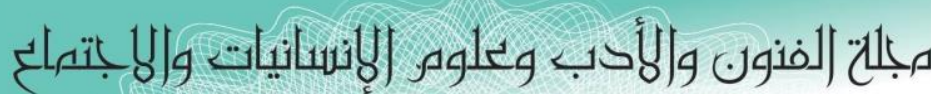 \\ Journal of Arts, Literature, Humanities and Social Sciences}

ISSN online: 2414 - 3383

ISSN print: 2616 - 3810

\section{العدد (41) آب - أغسطس 2019}

LALHSS

خامساً: خطة البحث

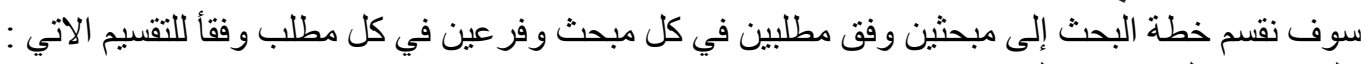

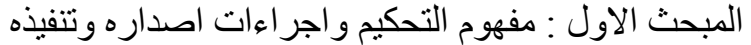

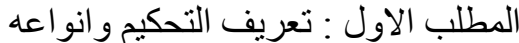

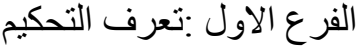
الفرع الثاني : انواع التحكيم التحكيم

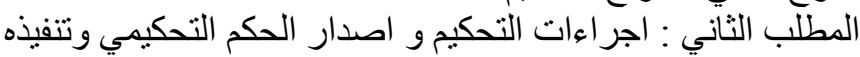

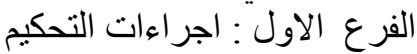

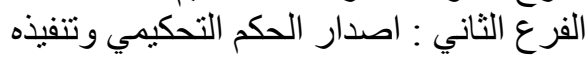
المبحث الثناني :موقف النظام القانوني في العر اقي من التئ التحكيم ومدى ممارسة في عقود النفط العر اقية

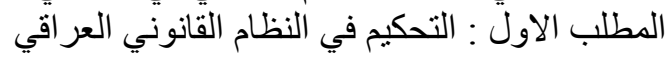

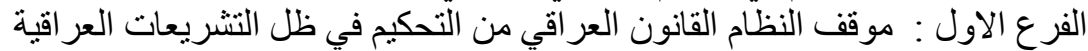

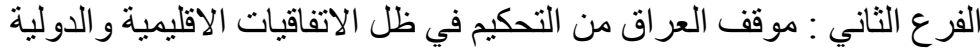

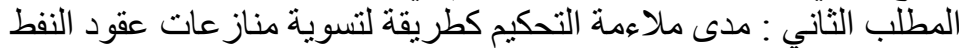

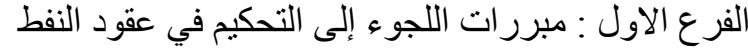
الفرع الثاني : مدى ممارسة التحكيم في عقود النفط العر اقية التية

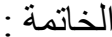

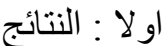
ثانيا : التوصيات

\section{المبحث الاول \\ مفهوم التحكيم}

يعد التحكيم احدى وسائل حسم المنازعات وهو طريق استثنائي ويقوم على ارادة الاطر اف حيث حيث يلجأ اليه

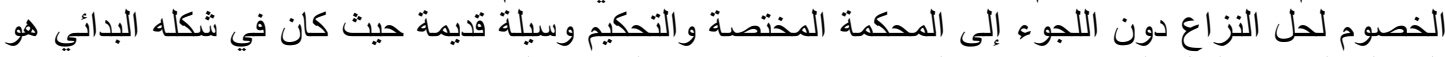

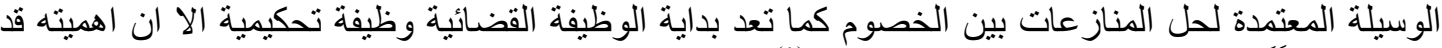

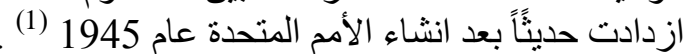

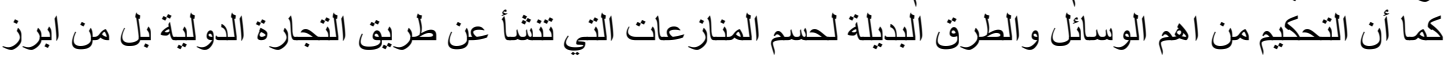

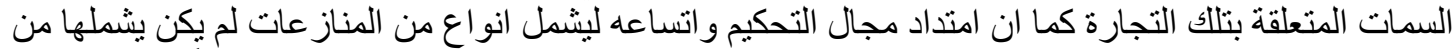

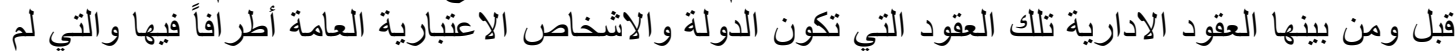

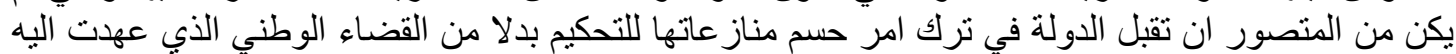

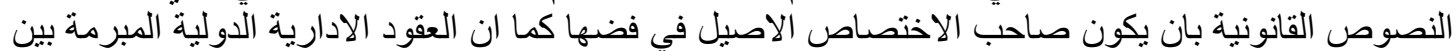

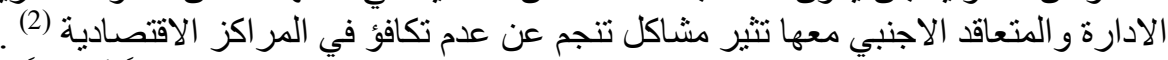

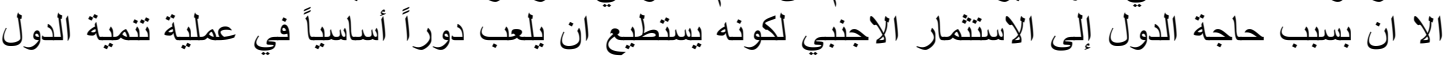

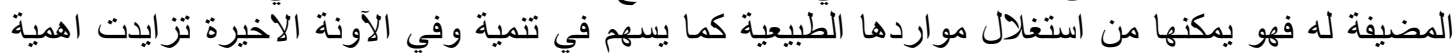

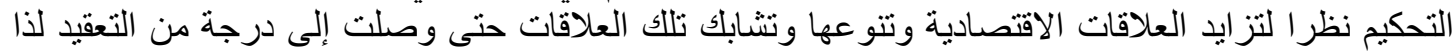

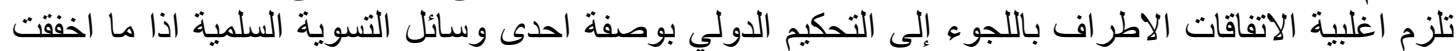

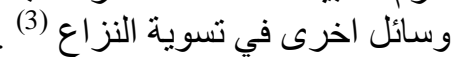
لهذا سوف نقسم هذا المبحث إلى مطلبين نبين في المطلب الاول تعرئ تعريف التحكيم وانواعه ونخصص المطلب الثناني لبيان اجر اءات اصدار الحكم التحكيمي وتنفيذه. 


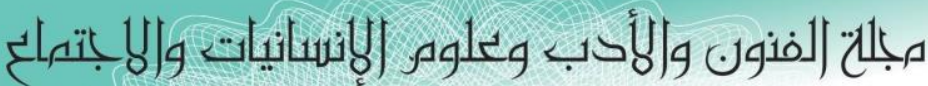

Journal of Arts, Literature, Humanities and Social Sciences

ISSN online: 2414 - 3383

ISSN print: 2616 - 3810

العدد (41) آب - أغسطس 2019

$$
\text { تعريف التحكيم وانواعه الاول }
$$

يقتض در اسة هذا المطلب تقسيمه إلى فرعين نين في الفرع الاولى تعريف التحكيم ونبين في الفرع الثاني

الفرع الاول: تعريف التحكيم التمبيم

التحكيم لغة : هو التفويض في الحكم ، فهو ماخوذ من حكمة واحكامة فاستحكم اي صار محكما في ماله تحكيما

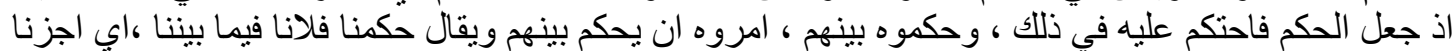

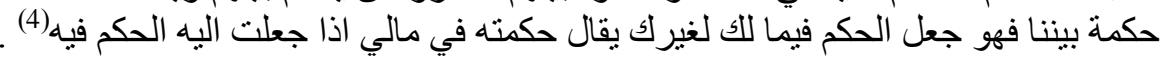

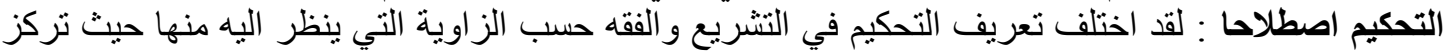

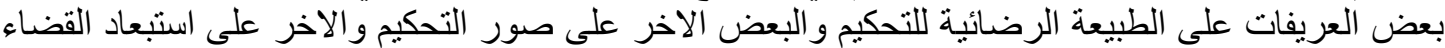

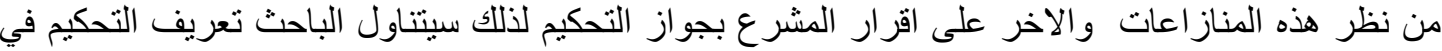

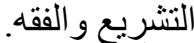

$$
\text { أولاً: تعريف التحكيم في التشريع التهريع }
$$

عرف المشرع الفرنسي التحكيم بانه اجراء خاص لتسوية الخياء التهات بواسطة محكمة تحكيم يعهد اليها الاطر اف

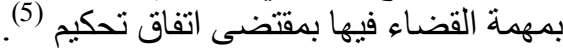
وقد عرفه المشرع المصري في المادة العاثرة من القانون (27) لعام 1994 بانه اتفاق الطرفين على الالتجاء

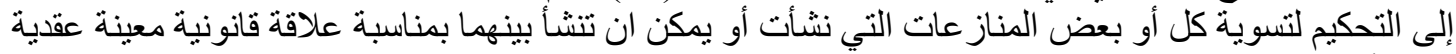

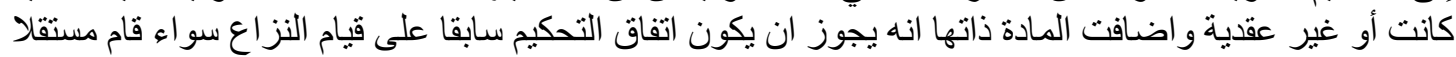

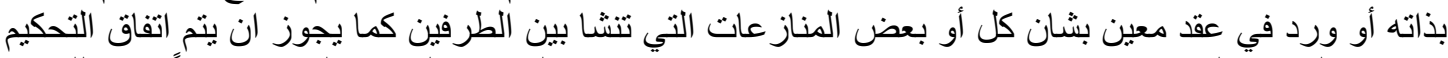

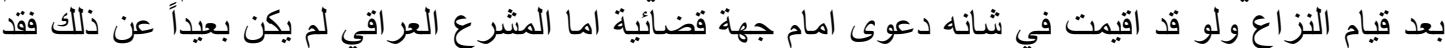
اكتفى بالنص على جو از التحكيم في نزاع معين وكذللك الاتفاق على التحكيم في جميع المناز عات التي التي تنشأ عن

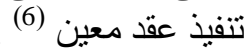

ثُانيا : تعريف التحكيم في الفقه

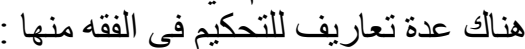

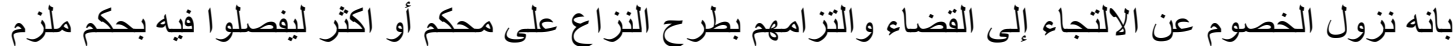

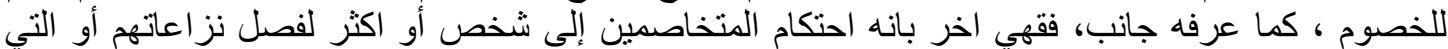

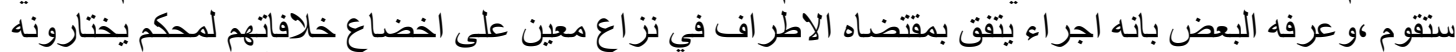

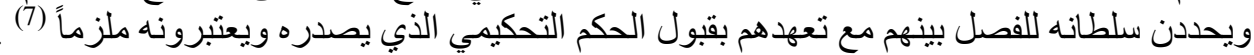

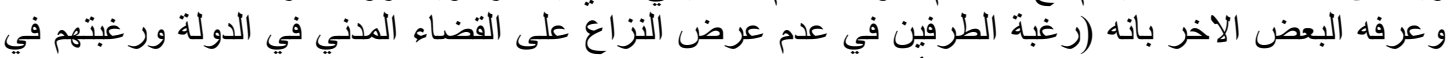

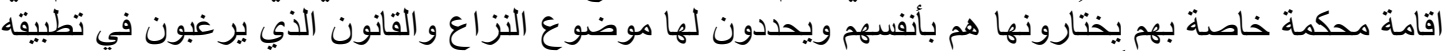

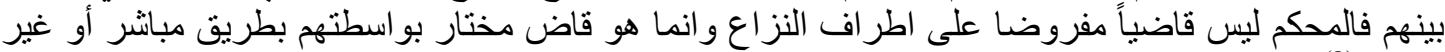

مباشر (8)

أو هو وسيلة مقبولة لحل الخلافات من خلال طرف ثالث في علاقات قانونية وذلك لما يتمتع به من استقلال

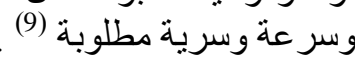
و عرفه الاستاذ رينيه دافييد بانه تقنية ترمي لحل قضية أو مسالة برو ابط بين شخصين أو اكثر بواسطة محكم أو أو بوني

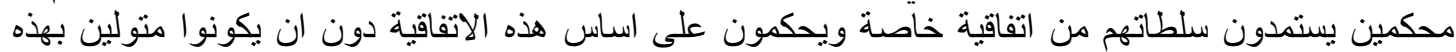

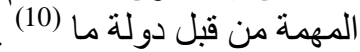

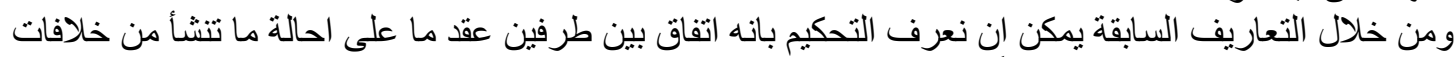

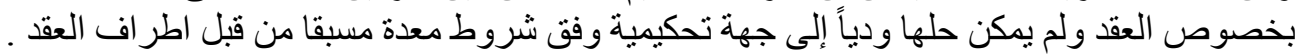




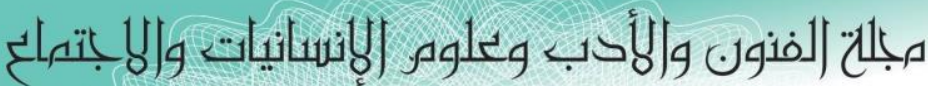

Journal of Arts, Literature, Humanities and Social Sciences

ISSN online: 2414 - 3383

ISSN print: 2616 - 3810

\section{العدد (41) آب - أغسطس 2019}

¿ALHSS

الفرع الثاني: انواع التحكيم

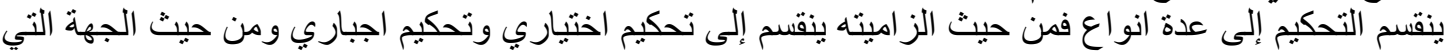

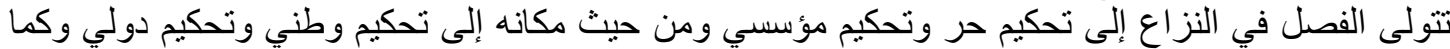

أولاً: التحكيم الاختياري والتحكيم الاجباري التحكيم الاختياري:

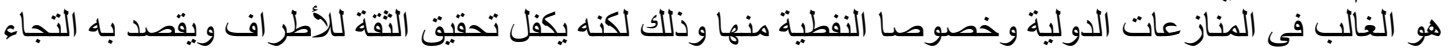

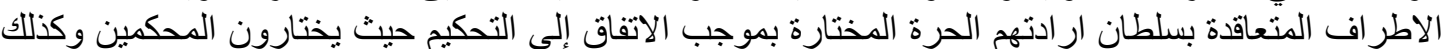

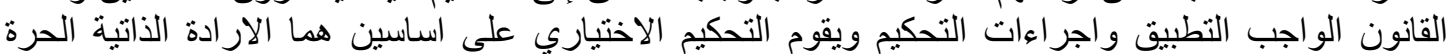

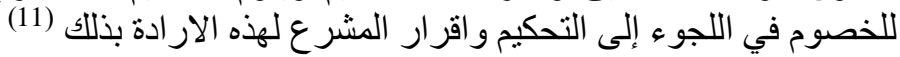
التحكيم الاجباري:

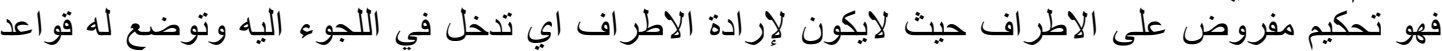

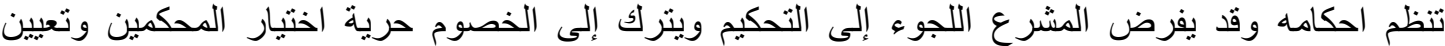

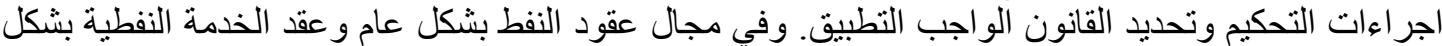

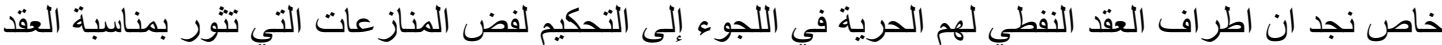

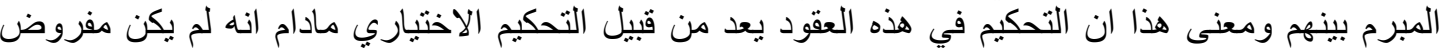
عليهم وان ار ادتهم قد اتجهت الئه اليه (12). وتجدر الاشارة إلى انه عندما لايلزم المشرع أليه أو اي قانون اخر الاطر اف المعنية صراحة باللجوء إلى التحكيم

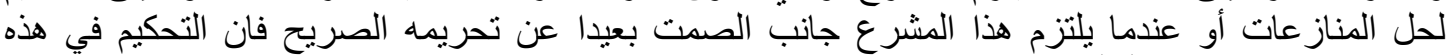

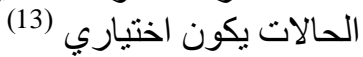
ثانيا : التحكيم الحر والتحكيم المؤسيسي. التحكيم الحر : التبا: و هو الاصل و الصورة التقليدية له حيث يختار اطر اف النزاع المحكمين في كل حالة وذللك دون التقبد بنظام دائم

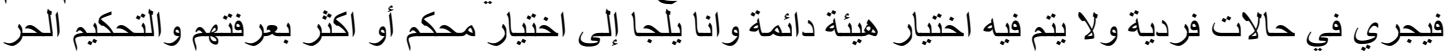

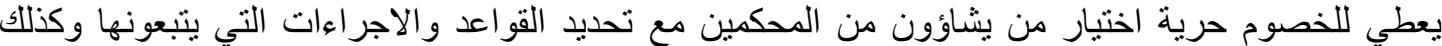

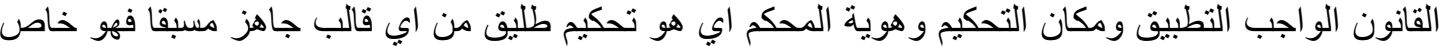

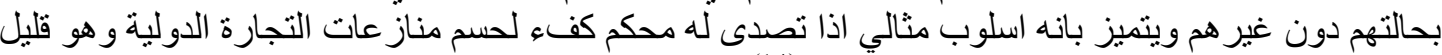

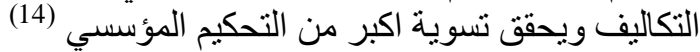

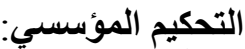

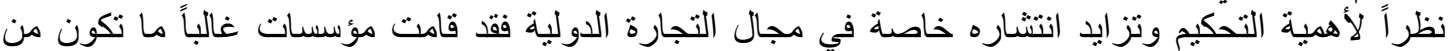

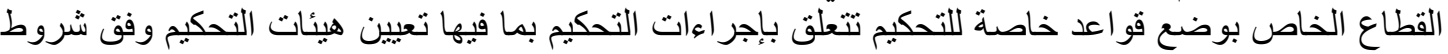

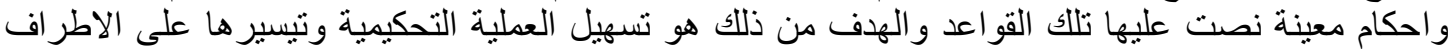

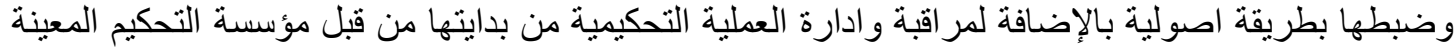

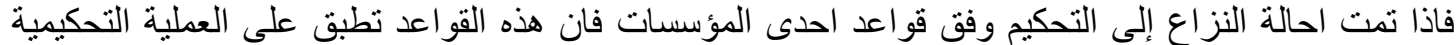

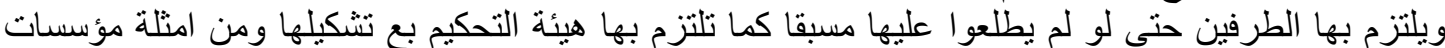

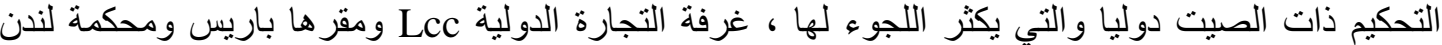

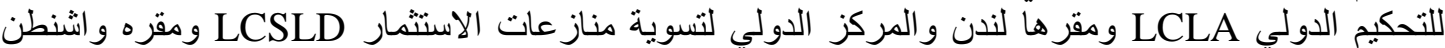

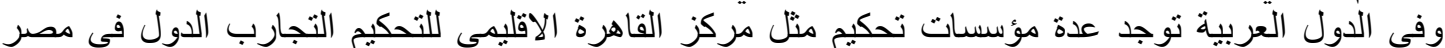

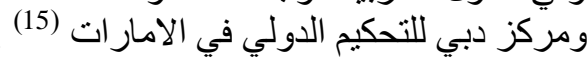




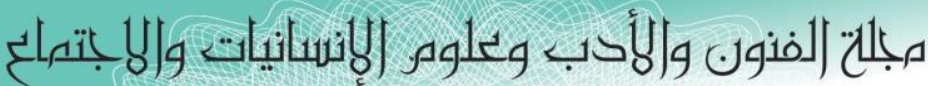

Journal of Arts, Literature, Humanities and Social Sciences

ISSN online: 2414 - 3383

ISSN print: 2616 - 3810

\section{العدد (41) آب - أغسطس 2019}

LALHSS

ثالثا : التحكيم الوطني والتحكيم الاولي. التحكيم الوطني:

و هو الذي يتحدد على أسـاس النطاق المكاني أو الاقليمي ويجري داخل الدولة التي تلجأ الاطر اف المعنية فيها

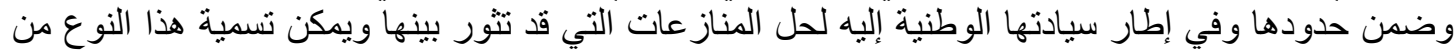

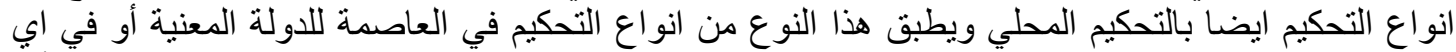

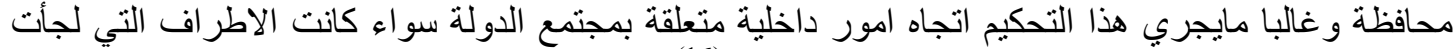

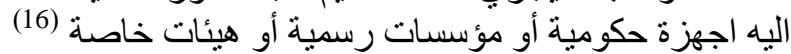

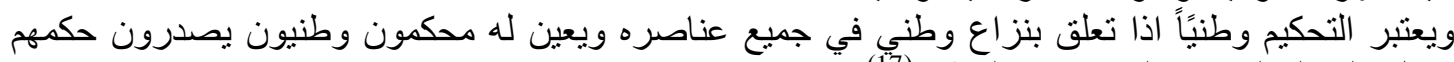

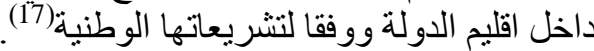

التحكيم الاولي:

وهو الذي ينتمي بعناصره المختلفة لأكثر من دولة ويثثير عدة صعوبات مثل القانون الواجب التطبيق على اتفاق

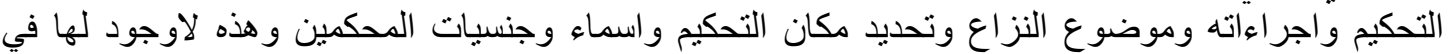

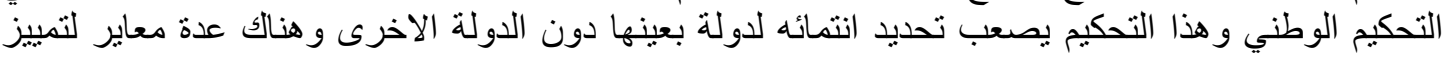

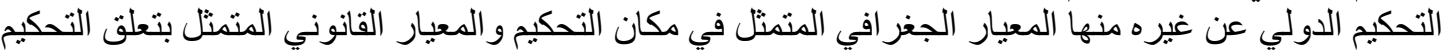

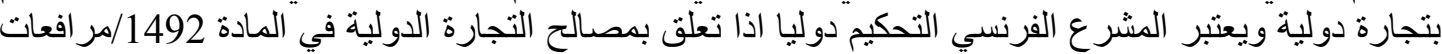
اما المشرع المصري فقد ربط الصفة الدولية بالصفة التجارية في المادة (3) من قانون التحكيم رقم (27) لسنة (18) 1994 ولايكاد أي عقد من العقود التجارة الدولية وخصوصا العقود النفطية يخلو من النص على احالة المنازعات

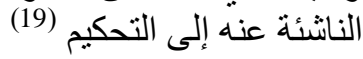

\section{اجراءات التحكيم و اصدار الحكم الثاني التحكيمي وتثفيذه}

يقصد بإجراءات التحكيم بمعناها الواسع هو السير بالعملية التحكيمية من بدايتها وحتى نهايتها بصدور حكم

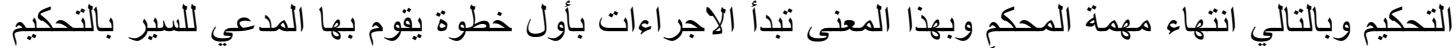

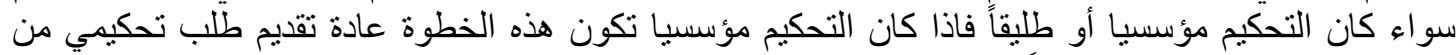
المحتكم لمؤسسة التحكيم متضمناً البيانات التي تتص عليها قو اعد التحكيم في المؤسسة ومنها فونا اسم طالب التحكيم و المحتكم ضده و عنو انهما واسم المحكم الذي يعينه أو يرشحه للتعبين اذا كانت هيئة التحكيم ستشكل من ثلاثنة

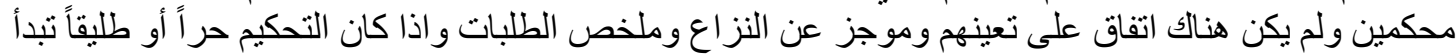
الخطوة الاولى بطلب يقدمه المحتكم للمحتكم ضده بأخطاره أو غير ذلف ذلك أو أو للمحكمة أو لسلطة تعبين المحكمين

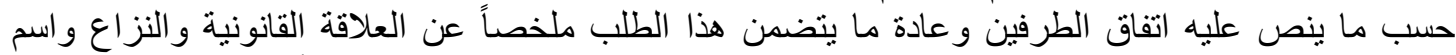

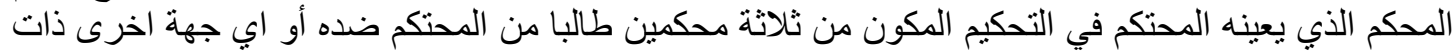
اختصاص تعبين المحكم الثاني خلال مدة المعي معينة.

وبالمعنى الضيق يقصد بإجر اءات التحكيم تللك القواعد الاجر ائية الواجب التباعها التبا بعد تشكيل هيئة التحكيم من قبل

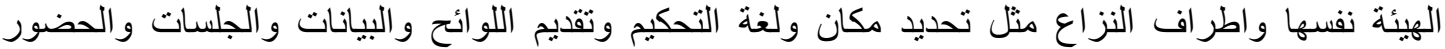

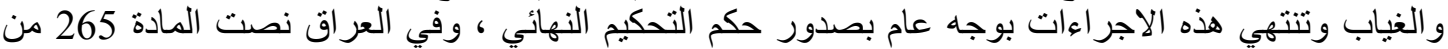

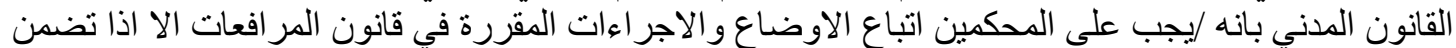

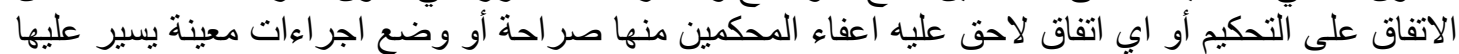

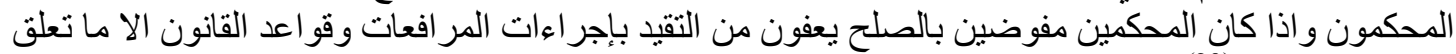

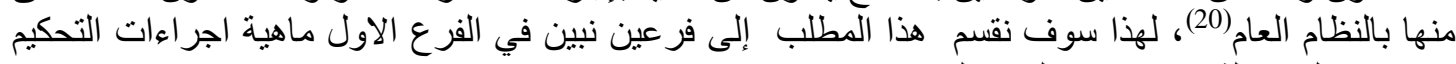
نخصص الفرع الثاني لإصدار الحكم التحكيمي وتنفيذه. لفالمان. 


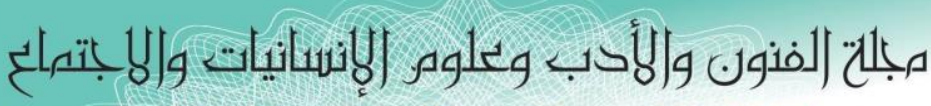
Journal of Arts, Literature, Humanities and Social Sciences

ISSN online: 2414 - 3383

ISSN print: 2616 - 3810

\section{العدد (41) آب - أغسطس 2019}

LALHSS

أولاً: اتفاق الاول: اجراف على التحكيم التحكيم

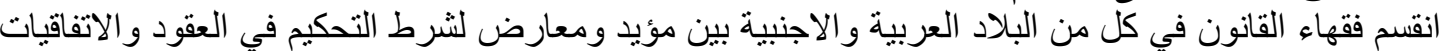

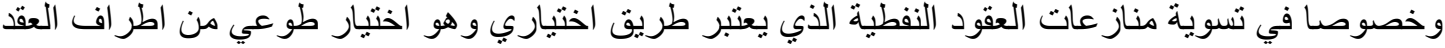

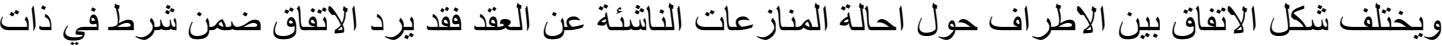

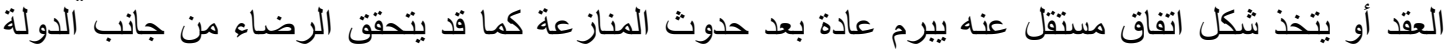

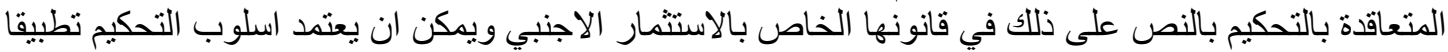

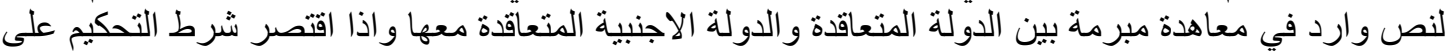

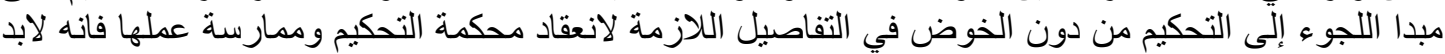

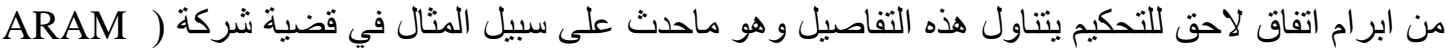
(CO

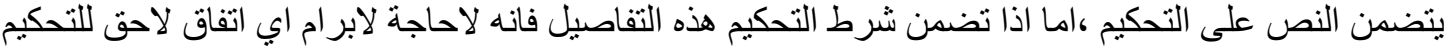

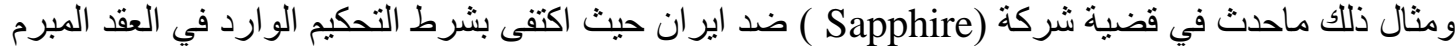

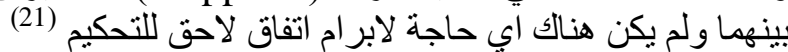

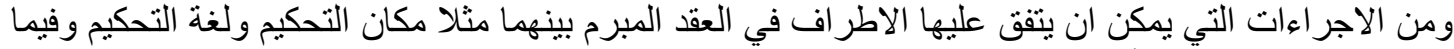

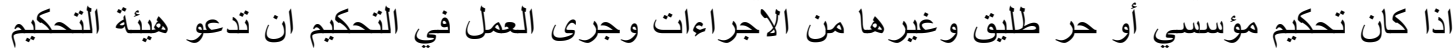

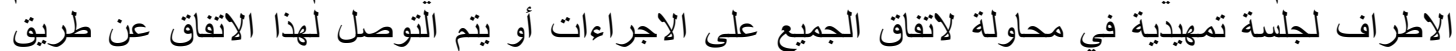

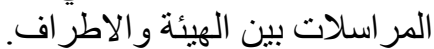

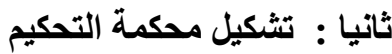

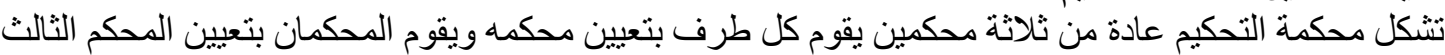

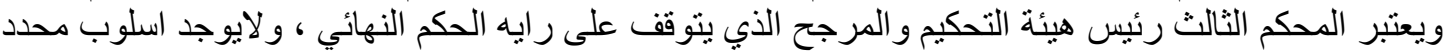

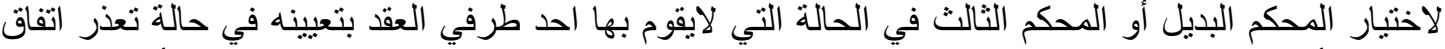

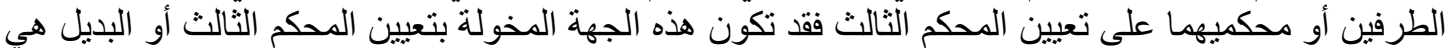

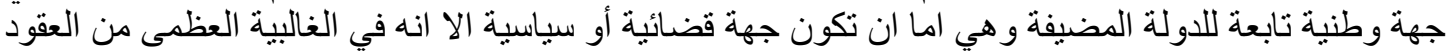

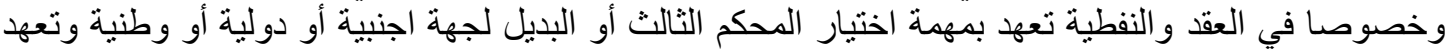

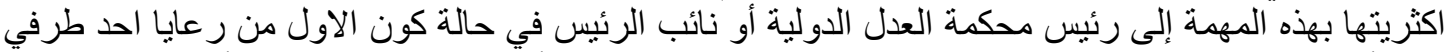

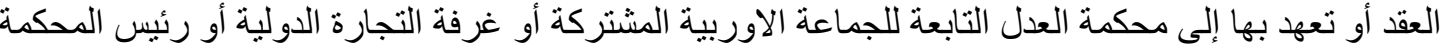

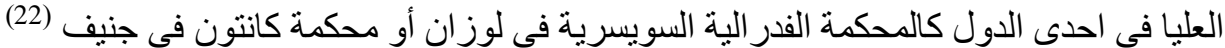

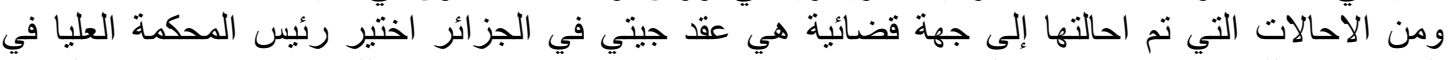

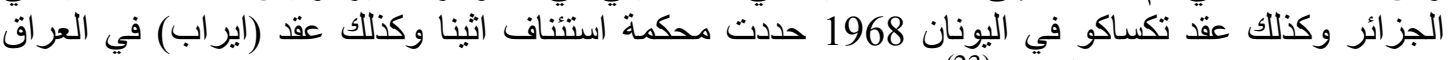

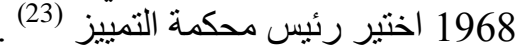

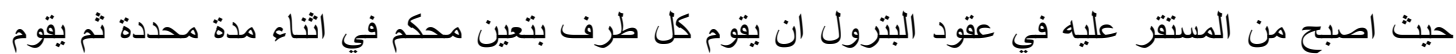

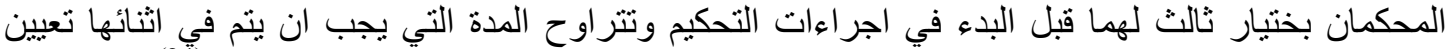

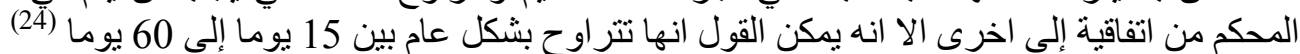
ثالثاً: مقر التحكيم

يقصد بمقر التحكيم المكان الذي سيجري فيه التحكيم و الذي يتعن صدور الحكم النهائي فيه ولهذا المكان اهمية

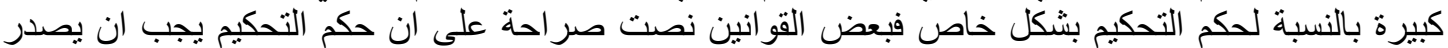

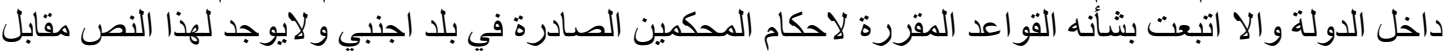

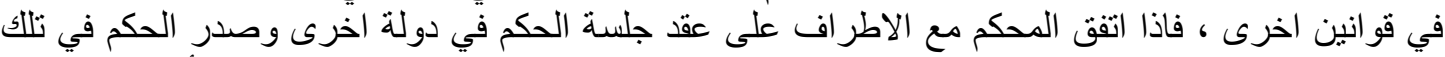

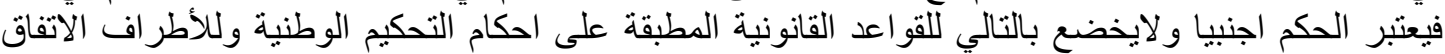

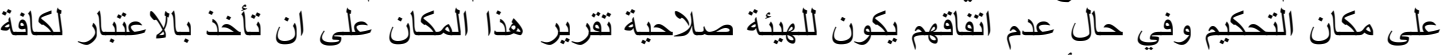

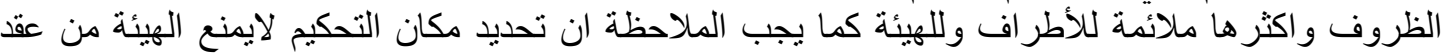


مبلحت (لفنون والأدب وعلوه الإنسانيات والبانتهاع Journal of Arts, Literature, Humanities and Social Sciences

ISSN online: 2414 - 3383

ISSN print: 2616 - 3810

\section{العدد (41) آب - أغسطس 2019}

بعض الجلسات في غير ذلك المكان حسب الظروف مثل الاستماع لناهد في مكان اقامته ومناقثنة خبير اجنبي

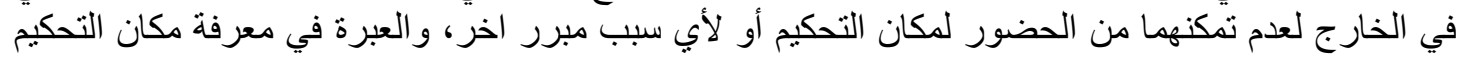
هي للمكان الذي تم فيه التحكيم فعلا وصدر فيه حكم التحكيم بغض النظي النظر عن المكان المحدد في اتفاق التحكيم

وفي عقود الاستثمار ات النفطية نجد ان الدول تردد غالبا بقبول انعقاد محكمة التحكيم في اقليم دولة اخرى سواء القاء

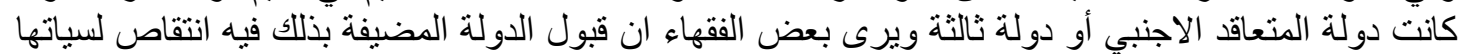

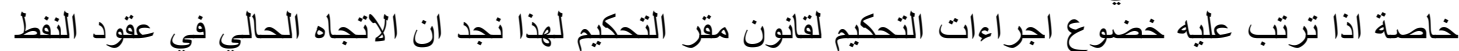

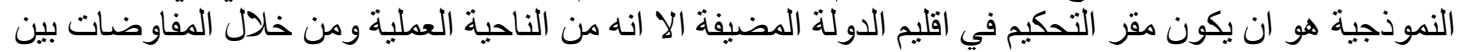

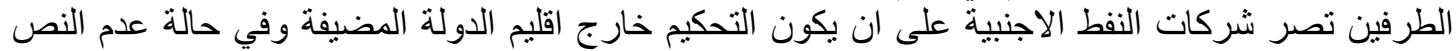

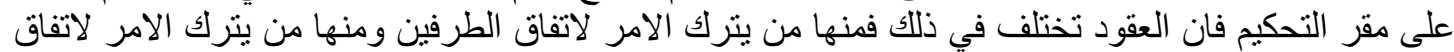

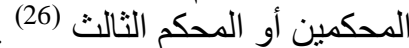

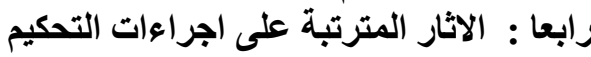

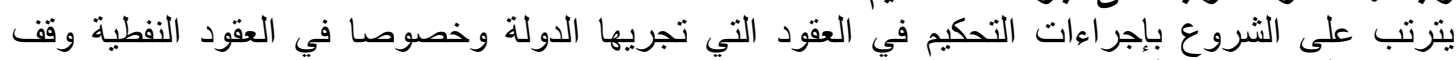

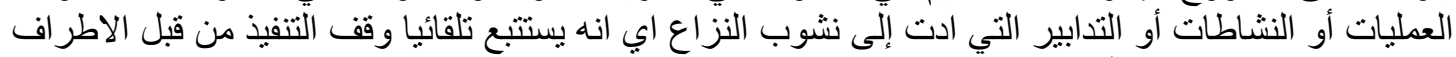

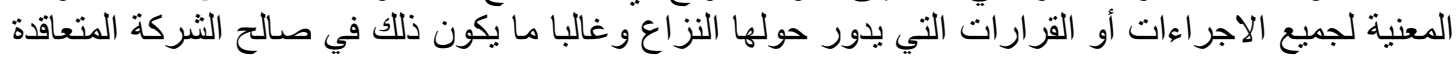

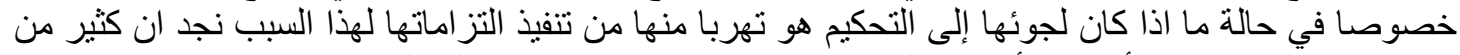

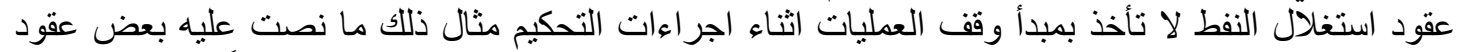

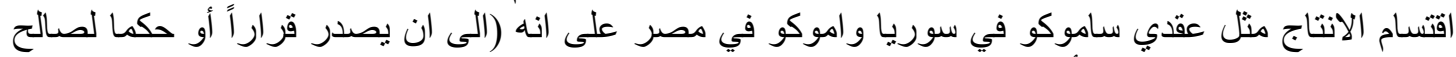

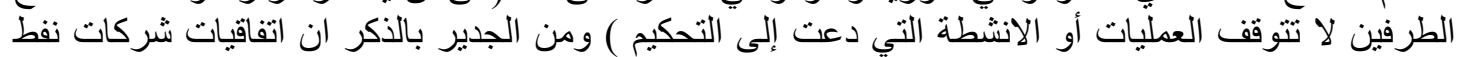

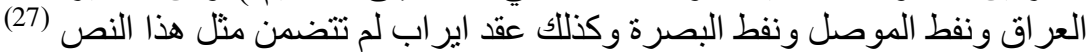

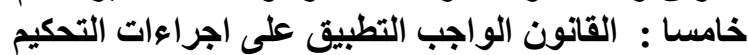

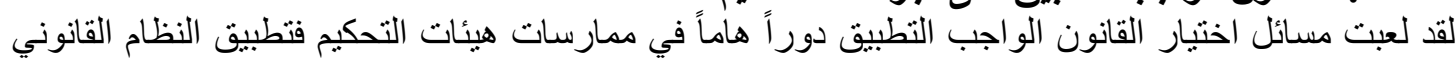

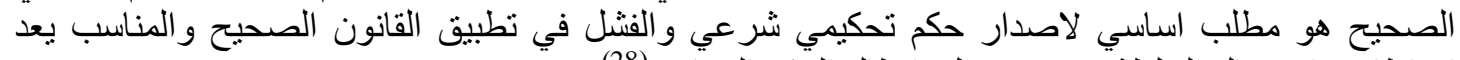

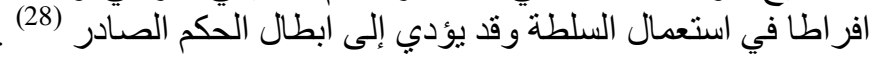

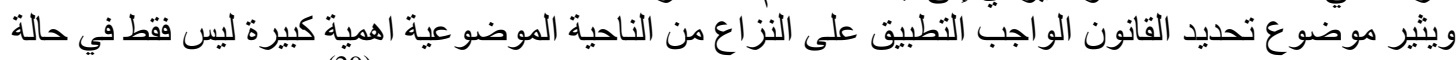

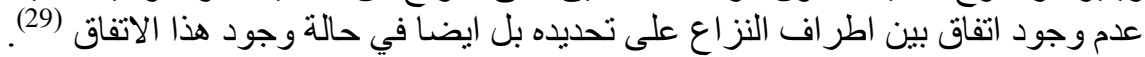

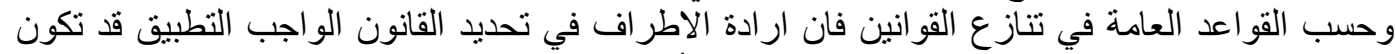

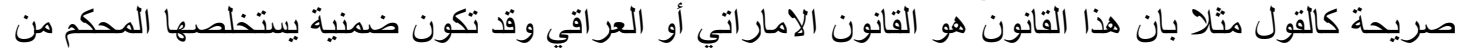

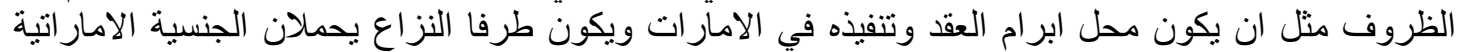

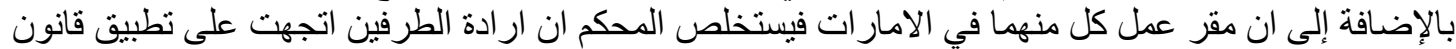
الامار اتي ويقرر تطبيقه بالعمل (30)

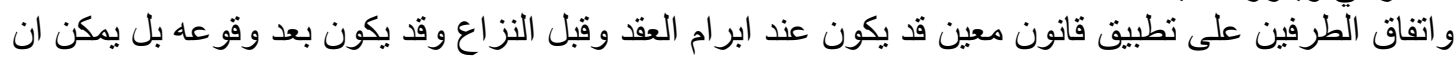

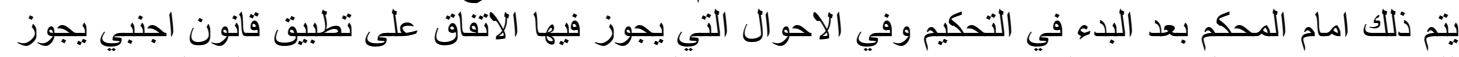

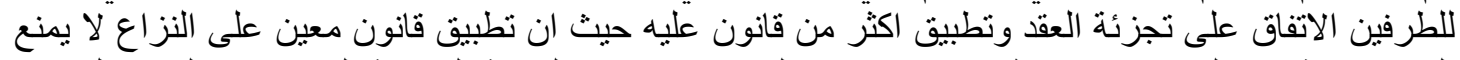

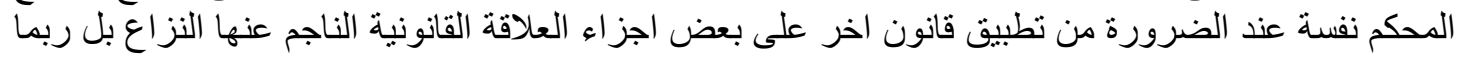

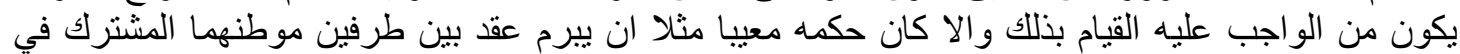

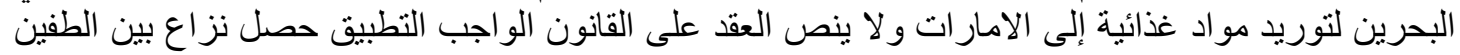

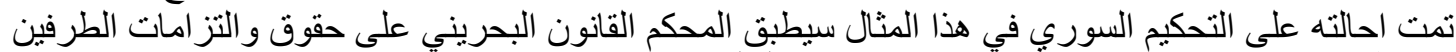

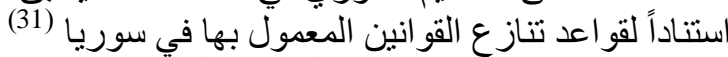

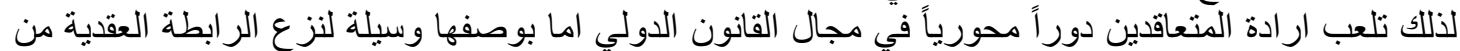

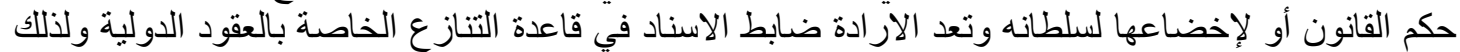

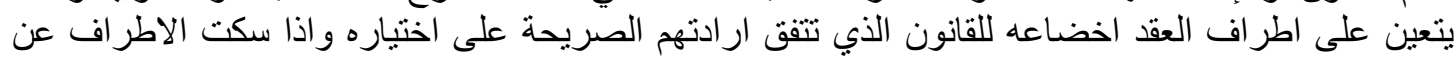


مبلحت (لفنون والأدب وعلوه الإنسانيات والبانتهاع Journal of Arts, Literature, Humanities and Social Sciences

ISSN online: 2414 - 3383

ISSN print: 2616 - 3810

\section{العدد (41) آب - أغسطس 2019}

الاختبار فيتعين البحث عن الارادة الضمنية عن طريق القرائن التي تدل على وجودها ويندر ان تخلو التوا عقود

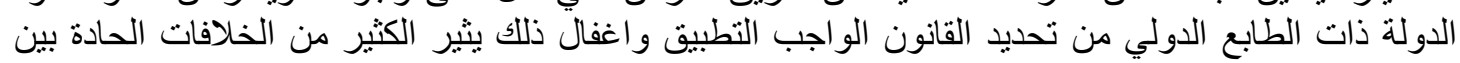

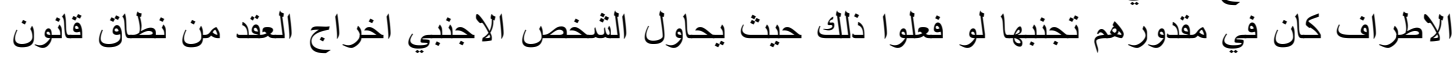

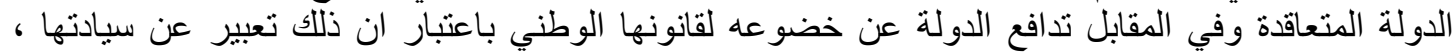

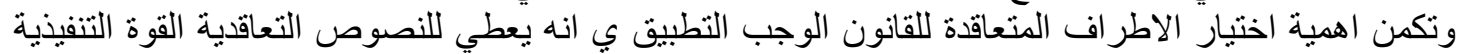

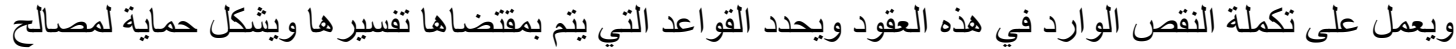

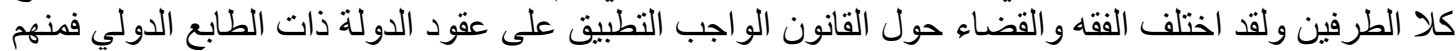

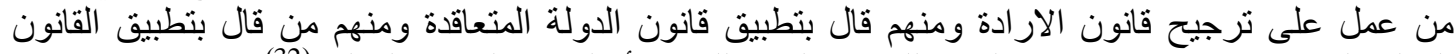

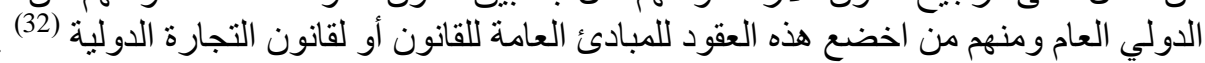

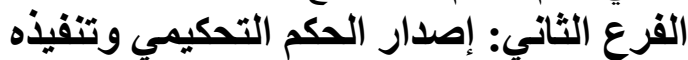

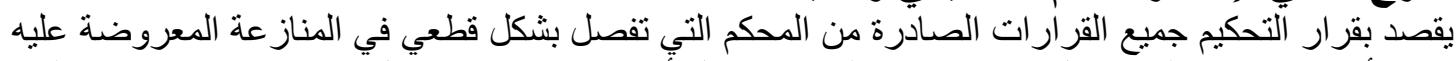

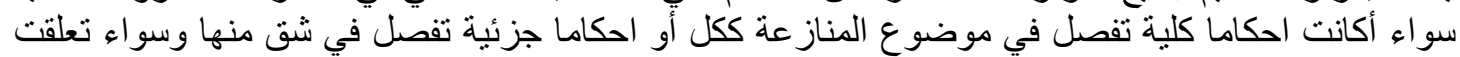

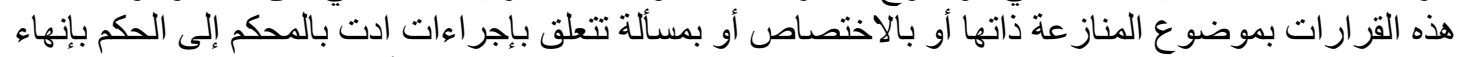

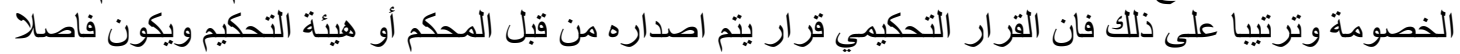

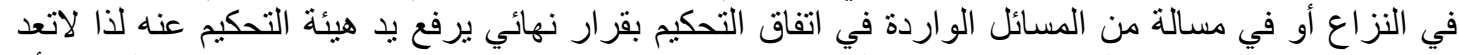

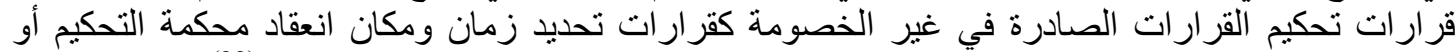

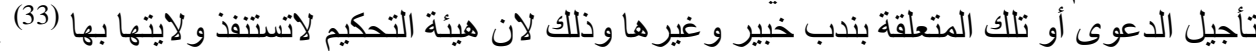

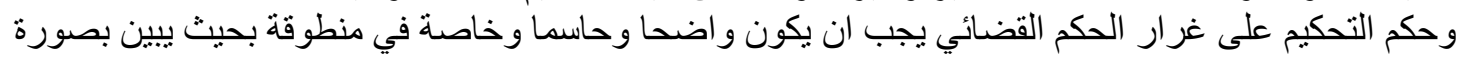

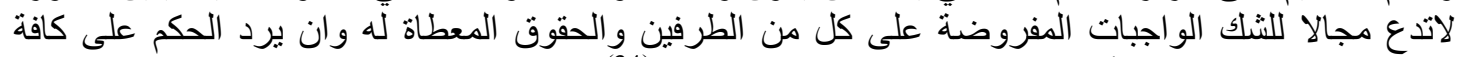

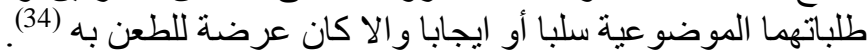

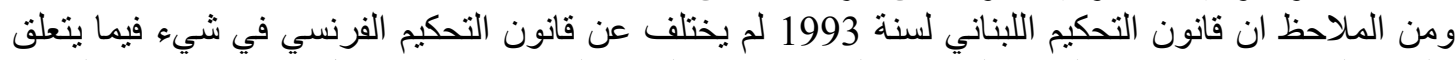

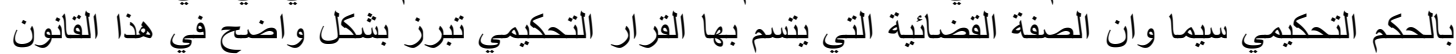

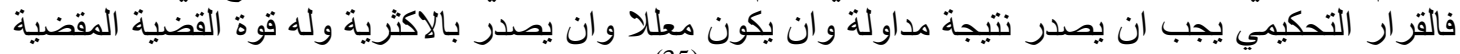

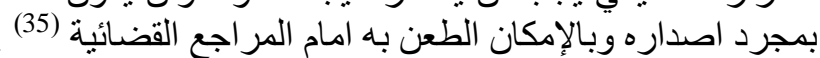

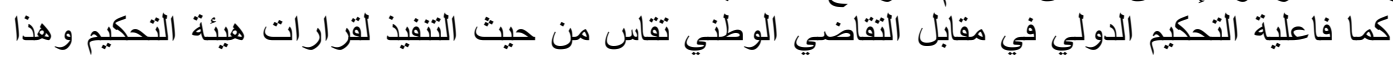

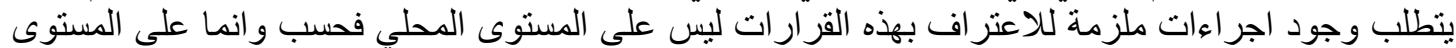
الدولي ايضاً (36) الديكاد

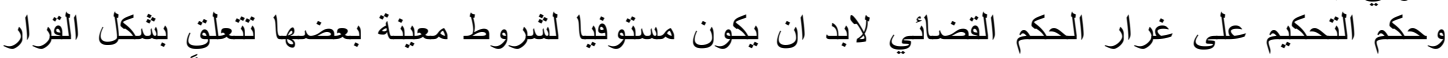

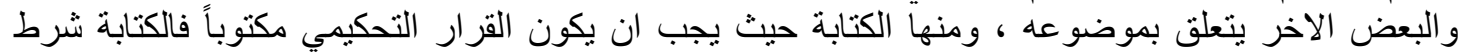

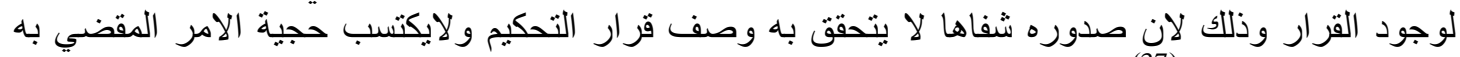

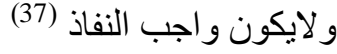

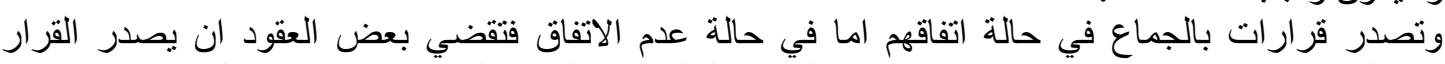

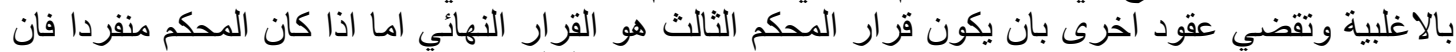

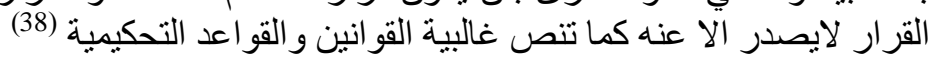

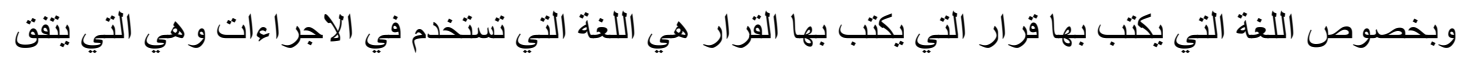

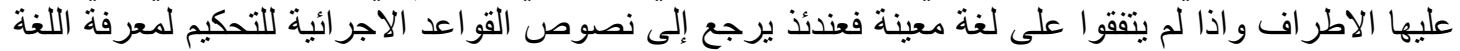

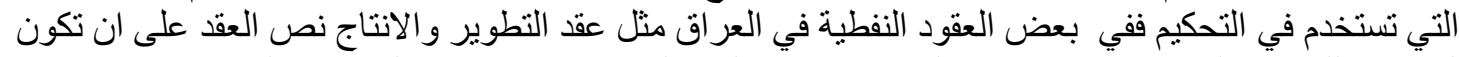

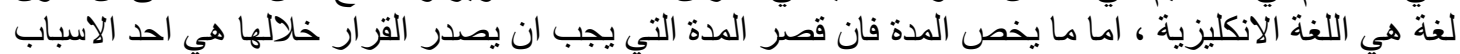

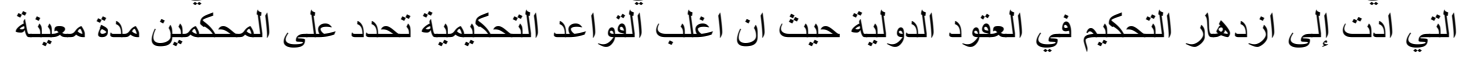

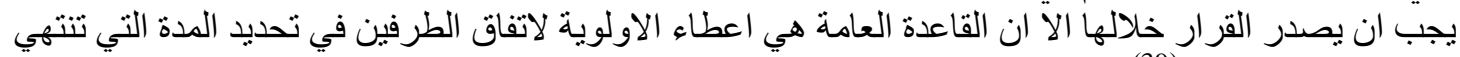

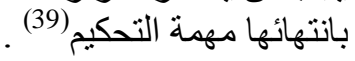




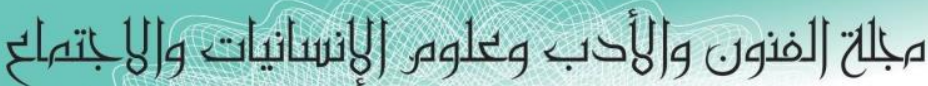

Journal of Arts, Literature, Humanities and Social Sciences

ISSN online: 2414 - 3383

ISSN print: 2616 - 3810

العدد (41) آب - أغسطس 2019

أما ما يخص تتفيذ القر ار التحكيمي فنود الاشارة هنا بان جميع القو انين تتفق على ان حكم التحكيم غير قابل للتنفيذ

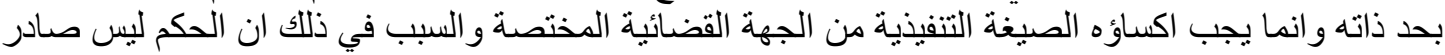

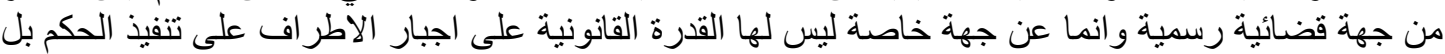

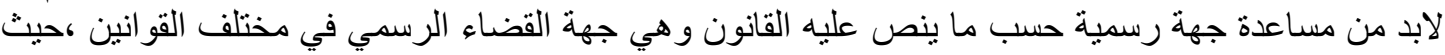

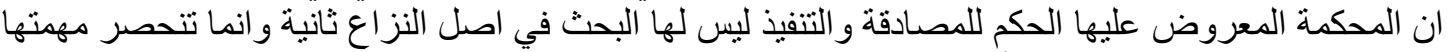

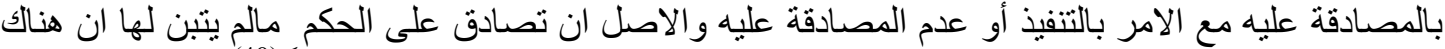

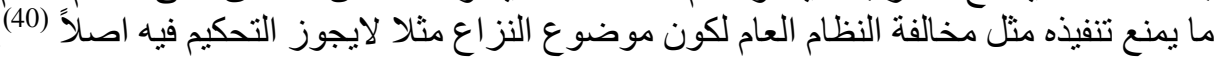

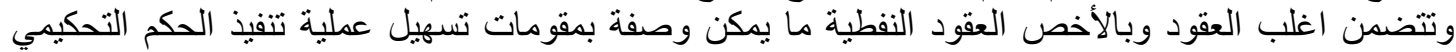

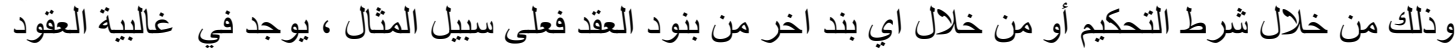

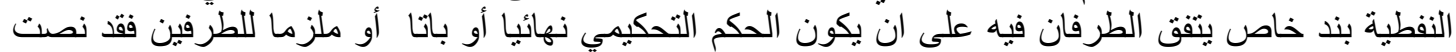

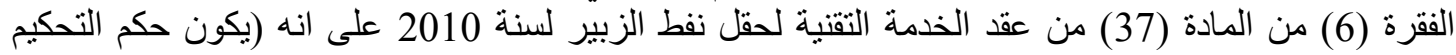

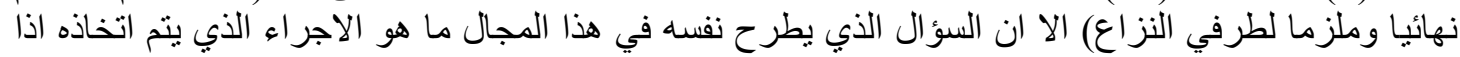

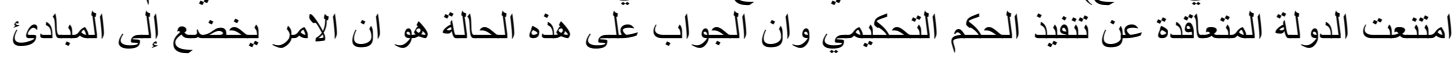

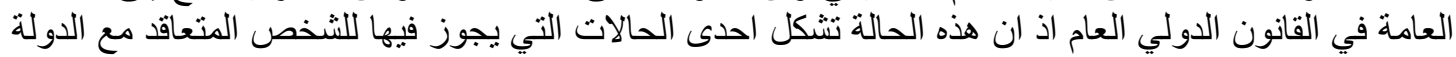

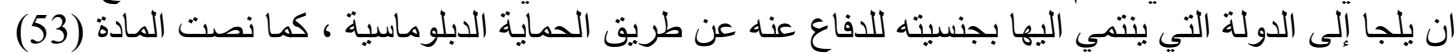

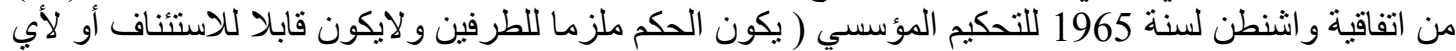

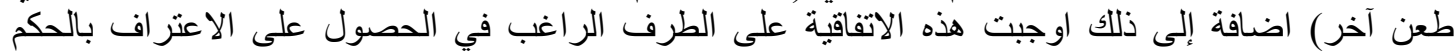

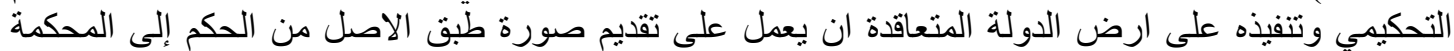

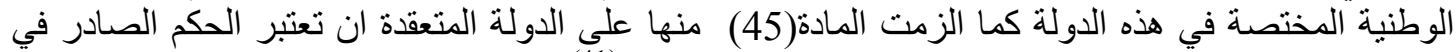
نطاق هذه الاتفاقية بمثابة حكم نهائي صادر النما عن محاكمها الوطنية (41)

\section{المبحث الثاني \\ موقف النظام القانوني في العراق من التحكيم ومديى ممارسة في عقود النفط العراقية}

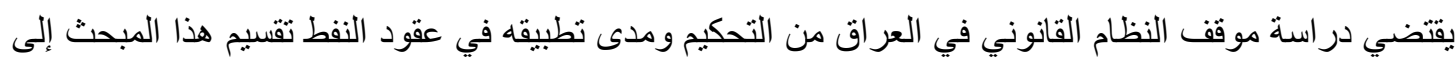

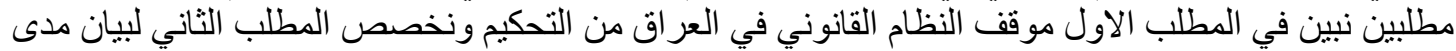
ممارسة التحكيم في عقود النفط العر اقية.

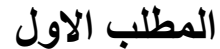 \\ موقف النظام القانوني العراقي من التحكيم}

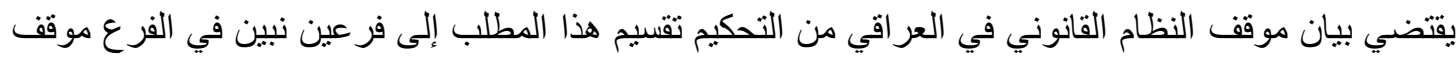

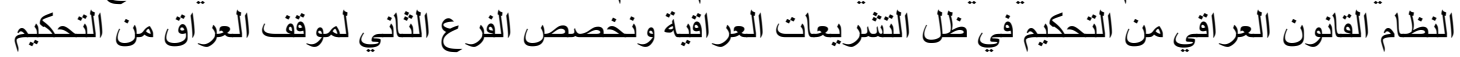
في ظل الاتفاقيات الاقليمبة والدولية.

القرع الاول: موقف النظام القانون العراقي من التحكيم في ظل التشئريعات العراقية

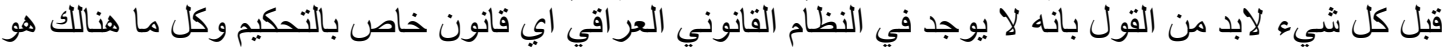

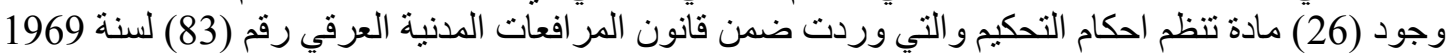

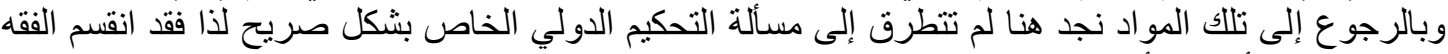

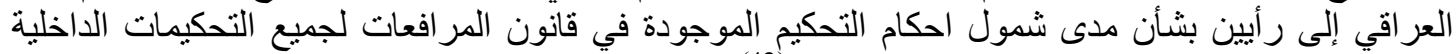

و الدولية ام انها خاصة بالتحكيم الداخلي دون الدولئ الدولي (42) . 


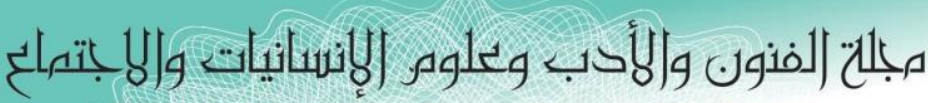
Journal of Arts, Literature, Humanities and Social Sciences

ISSN online: 2414 - 3383

ISSN print: 2616 - 3810

\section{العدد (41) آب - أغسطس 2019}

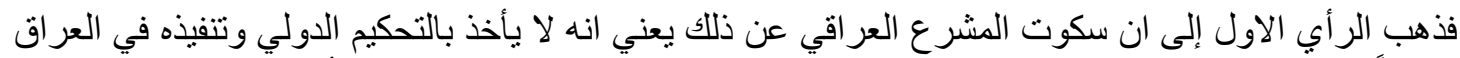

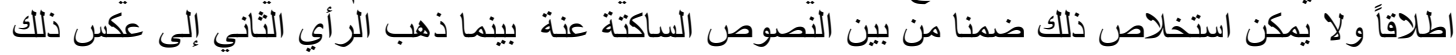

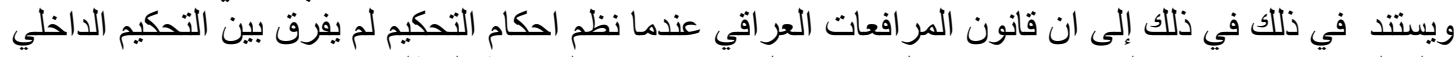

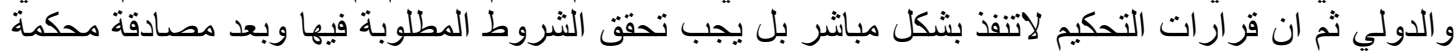

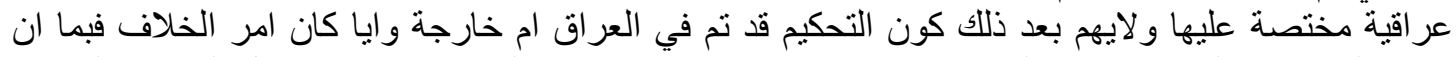

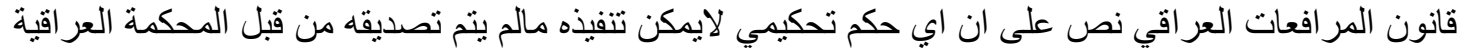

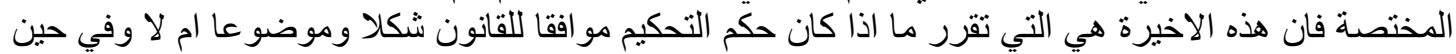

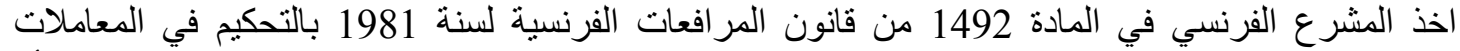

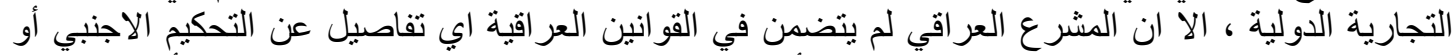

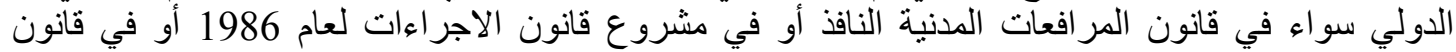

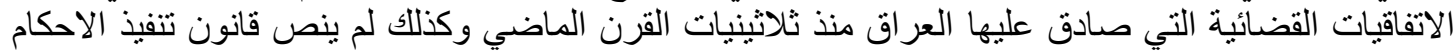

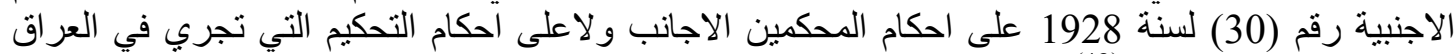

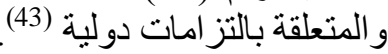

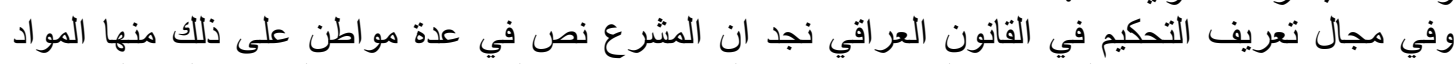

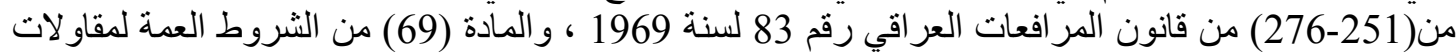

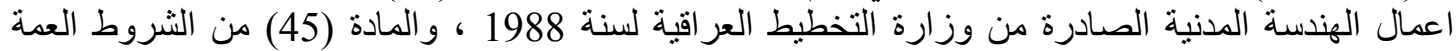

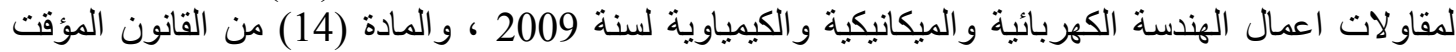

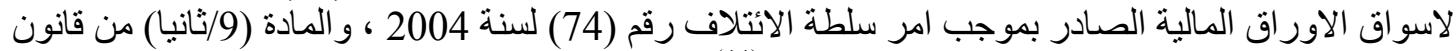

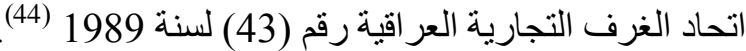

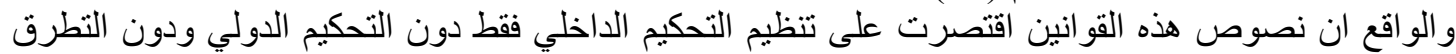

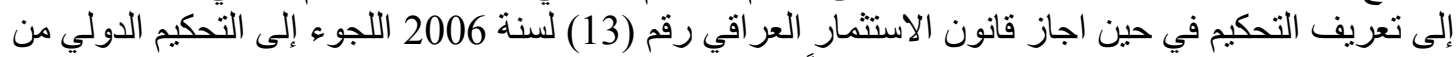

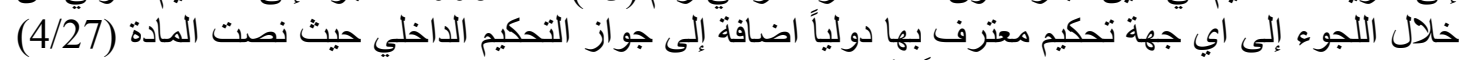

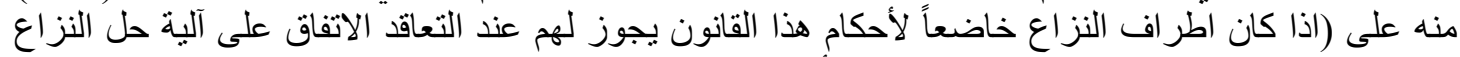

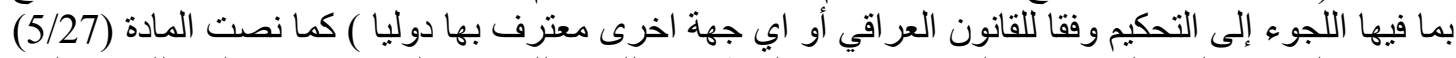

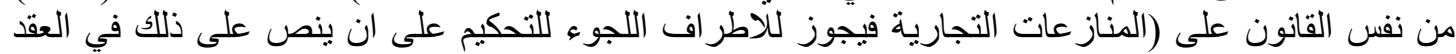

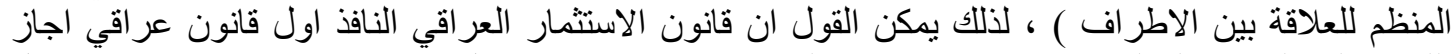

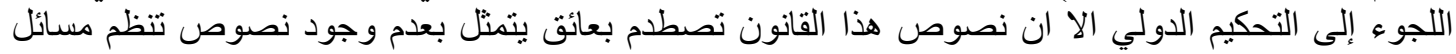

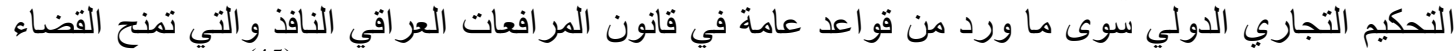

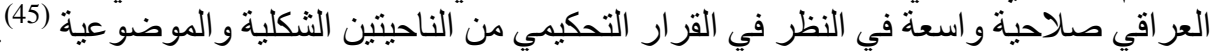

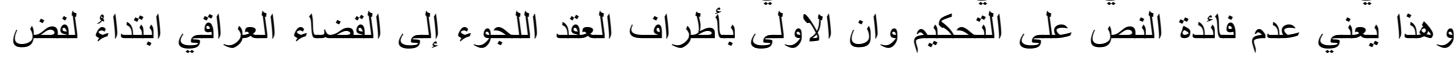

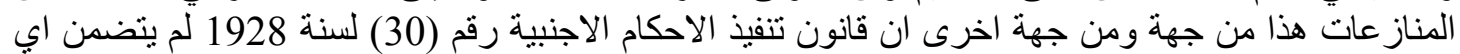

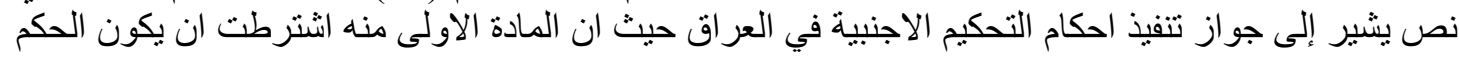

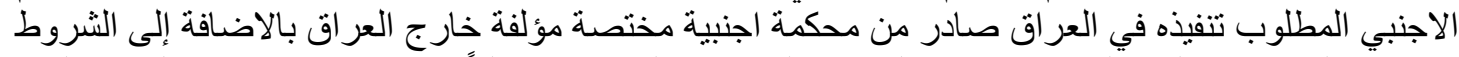

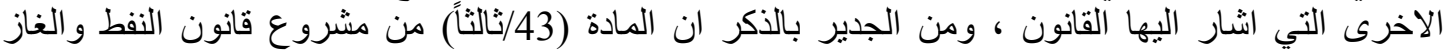

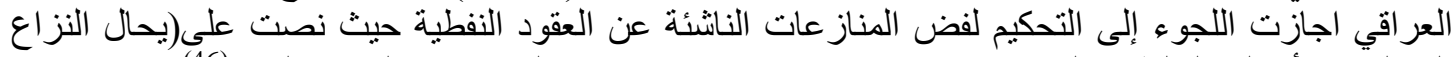

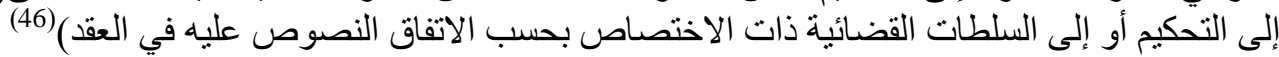

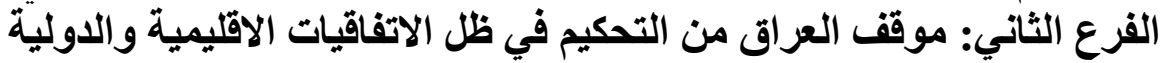

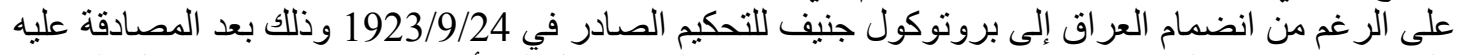

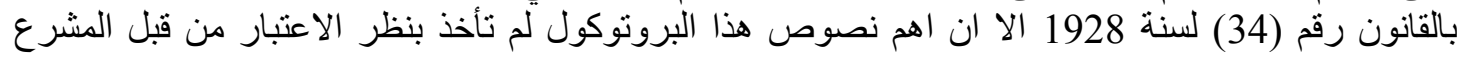

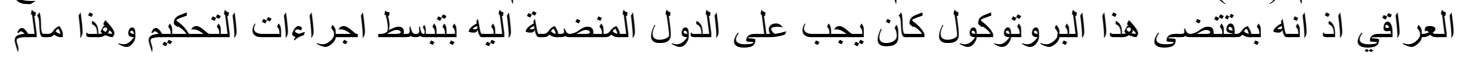

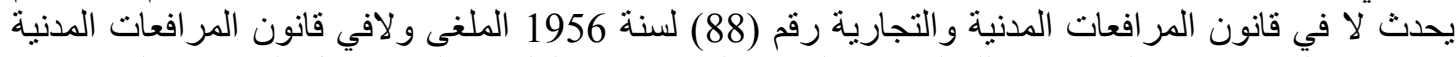

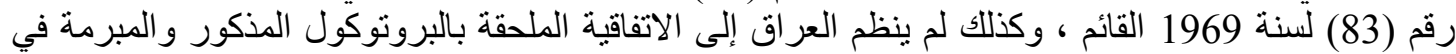




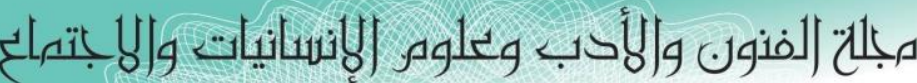

Journal of Arts, Literature, Humanities and Social Sciences

ISSN online: 2414 - 3383

ISSN print: 2616 - 3810

العدد (41) آب - أغسطس 2019

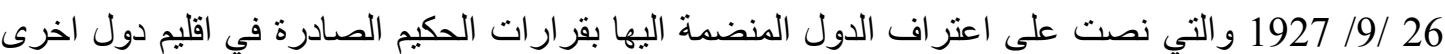

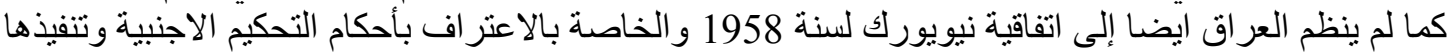

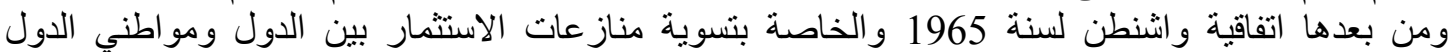

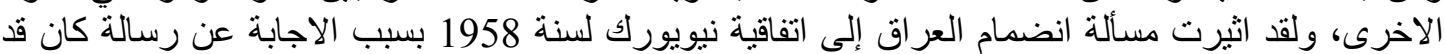

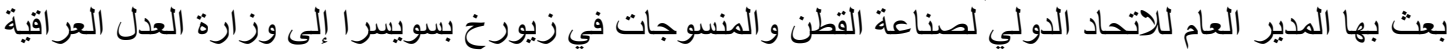

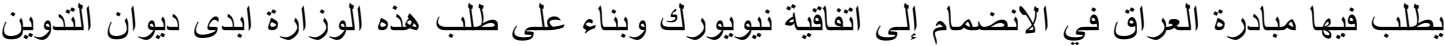

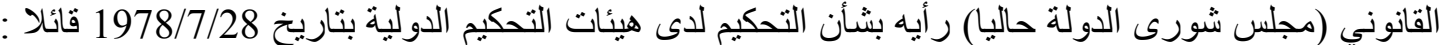

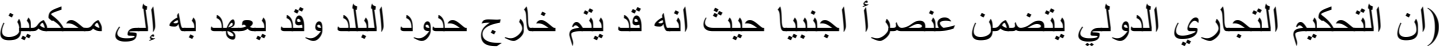

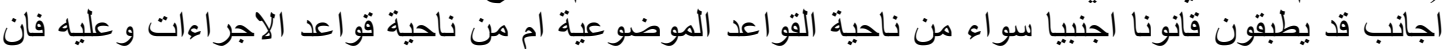

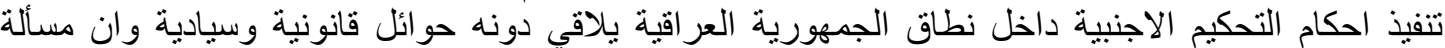

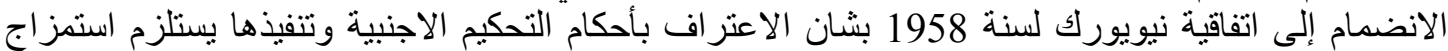

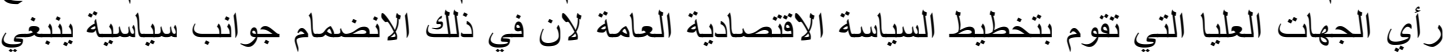

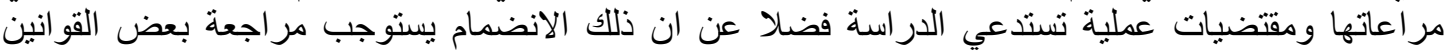
العر اقية وتعديلها بما يتلاءم واحكام هذه الاتفاقية كقانون تنفيذ الاحكام الاجنيبة وقانية الانية الانية المر افعات أو صدار قانون

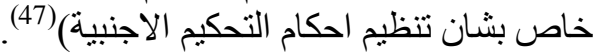

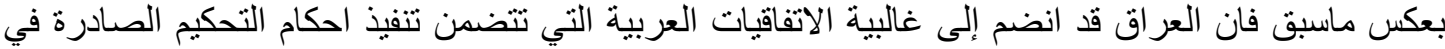

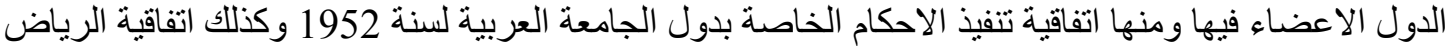

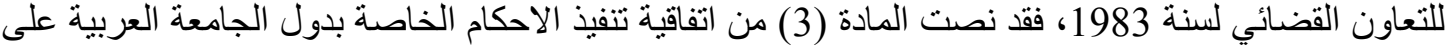

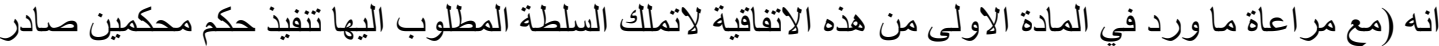

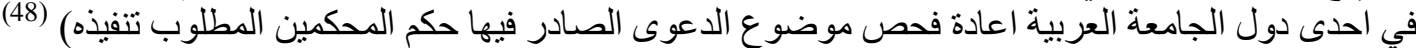

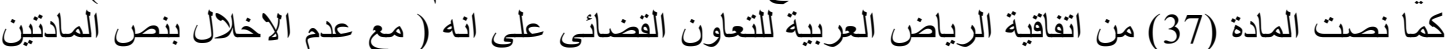

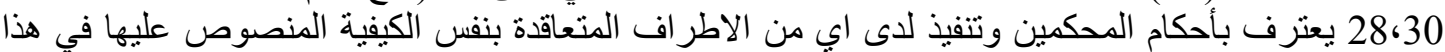

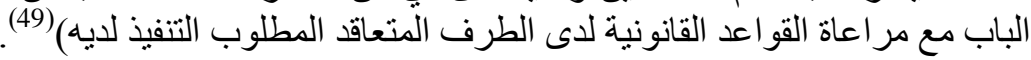

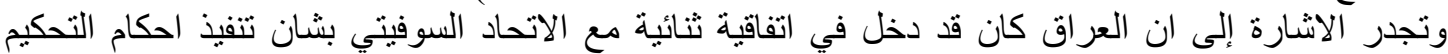

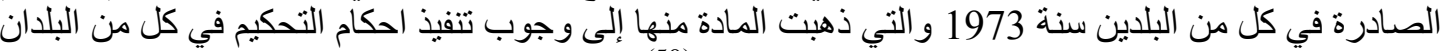

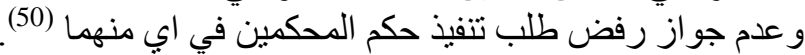

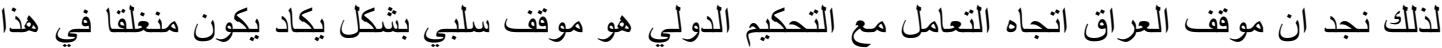

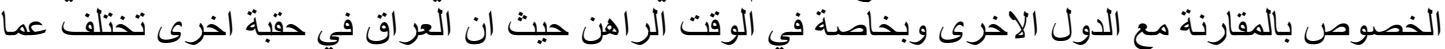

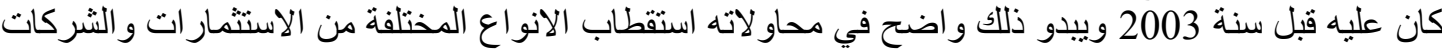
الاجنبية العاملة في المجالات المختلفة.

\section{مدى ملاعمة التحكيم كطريقة لتسويتّة مناز الثاني المات عقود التفط}

يقتضي در اسة هذا المطلب تقسيمه إلى فرعين نبين في الفرع الاول مبررات اللجوء إلى التحكيم في عقود النفط ونخصص الفرع الثاني لبيان مدى ممارسة التحكيم في عقود النفط العر اقية.

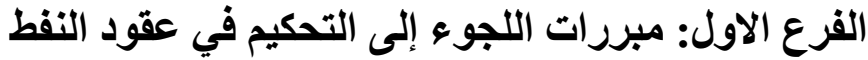

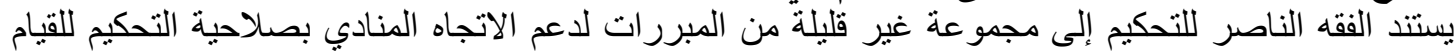
بمهمة الفصل في المناز عات التي تتشأ بين طرفي النزاع بشكل عام وفي عقود النفط بشُكل خاص ومن الهم هذه النه

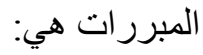




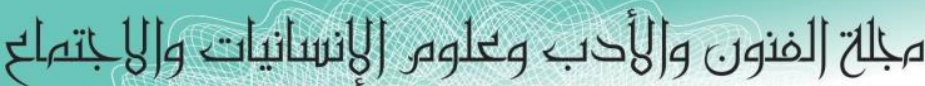

Journal of Arts, Literature, Humanities and Social Sciences

ISSN online: 2414 - 3383

ISSN print: 2616 - 3810

\section{العدد (41) آب - أغسطس 2019}

ЧALHSS

أولاً: حرية الطرفين في التحكيم :

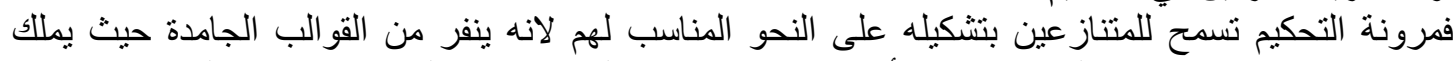

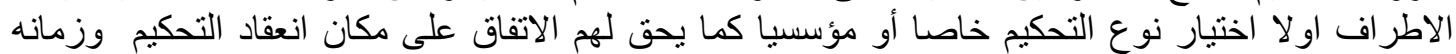

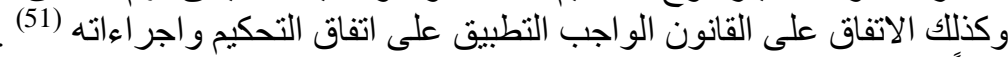

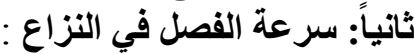

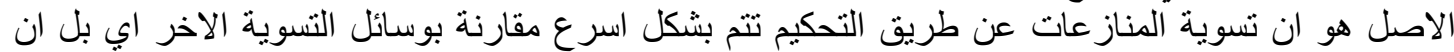

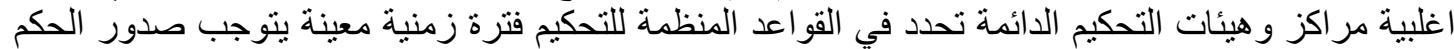

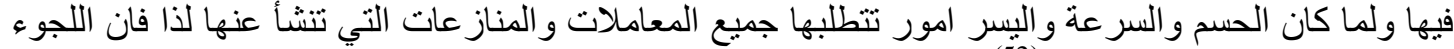

إلى التحكيم يحقق اهمية خاصة الهية (52) حيث يتميز بالسر عة في الاجر اءات وقلة في المصاريف اذا ما قورن مع ما يستغرقه اللجوء إلى القضاء من وقت التهاء

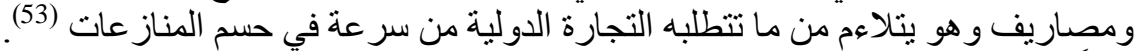

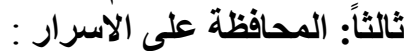

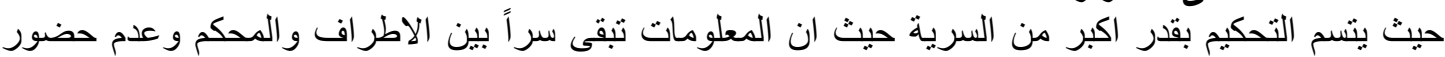

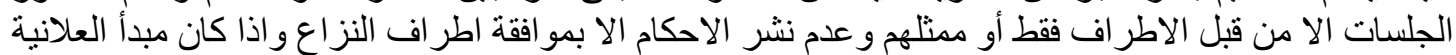

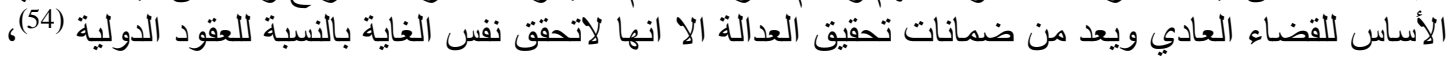

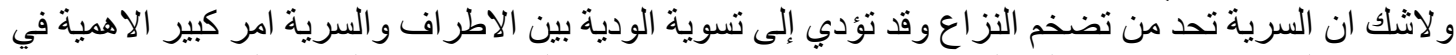

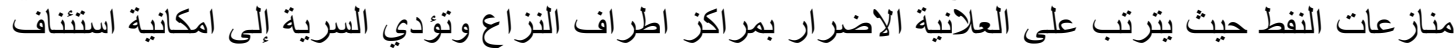
الاطر اف معاملتهم مستقبلا وقد ترتب على الحاطة التحكيم بهالة من السرية التامة أن غالبية التية احكام التحكيم لم يتم

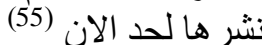

رابعاً: استقلالية وكفاءة وحياد هيئة التحكيم :

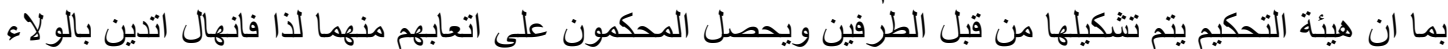

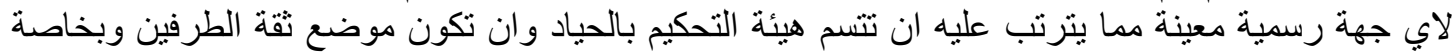

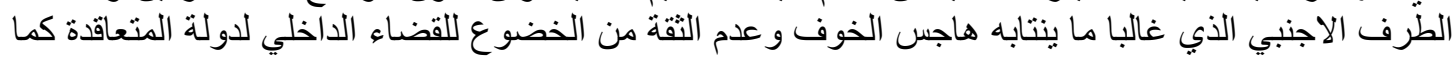

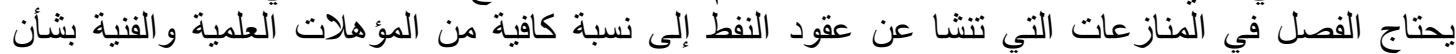

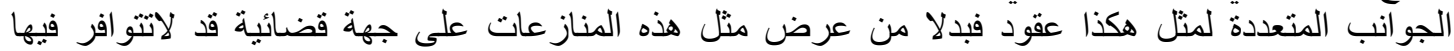

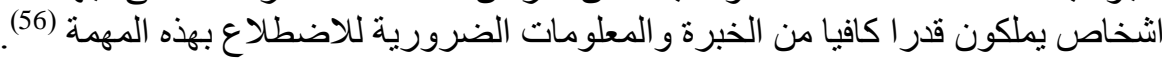

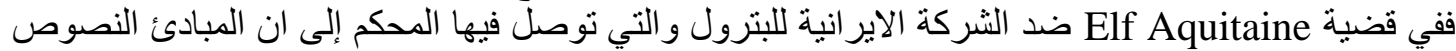

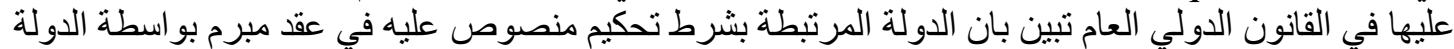

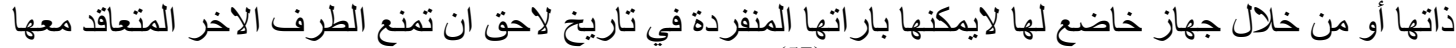

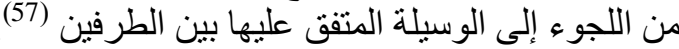

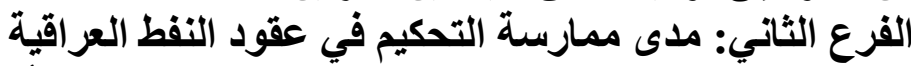

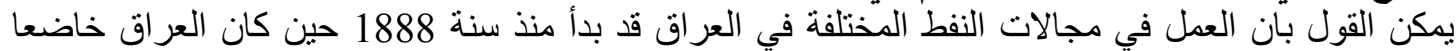

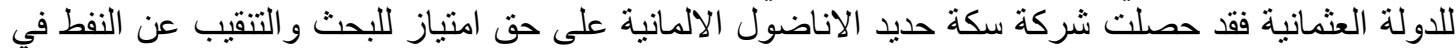

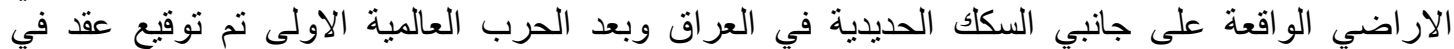

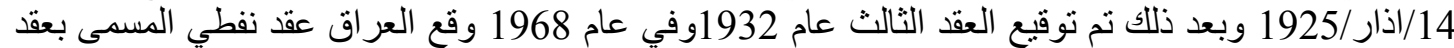

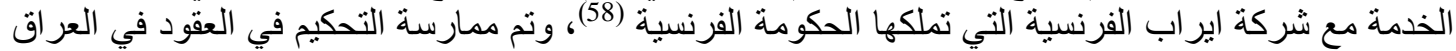
تبدأ المرحلة الاولى من سنة 1925 ولغاية 1958 حيث تضمنت المادة الر ابعة من العقد المبرم سنة 1925

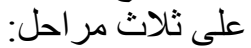

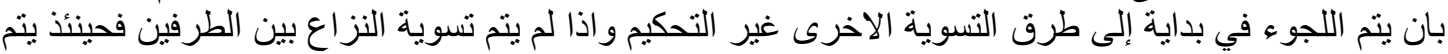

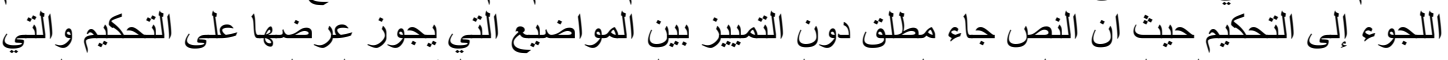

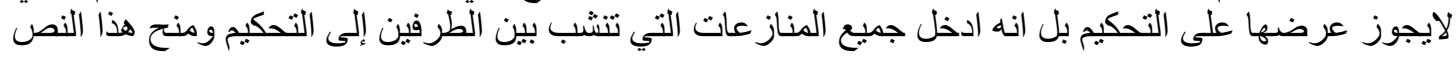




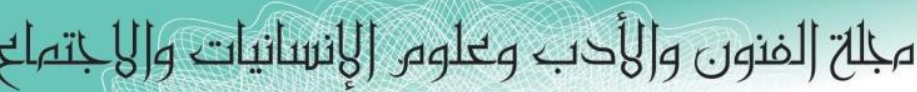
Journal of Arts, Literature, Humanities and Social Sciences

ISSN online: 2414 - 3383

ISSN print: 2616 - 3810

\section{العدد (41) آب - أغسطس 2019}

LALHSS

سلطة تعين المحكم الثالث عند الاختلاف عليه إلى رئيس محكمة العدل الدولية الدائمة كما بينت بان الدئ الحكم الذي الذي

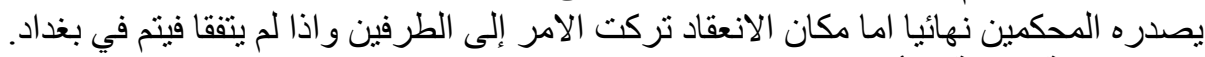

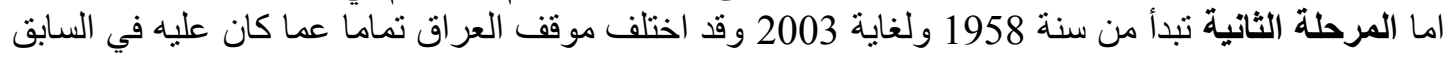

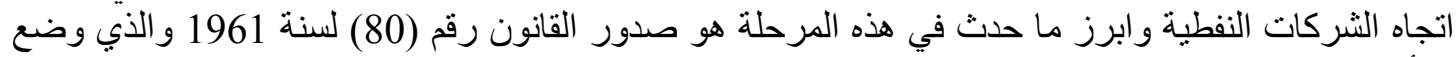

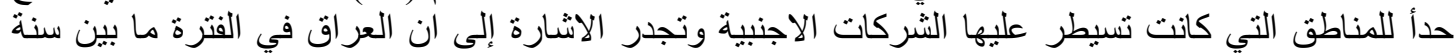

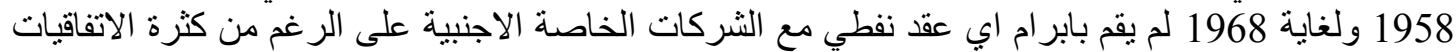

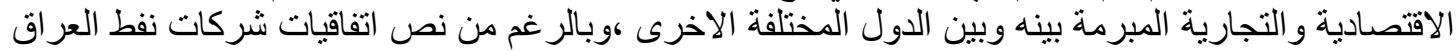

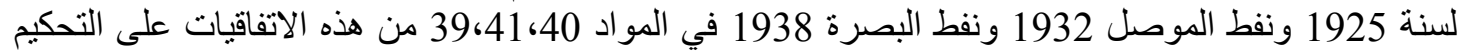
الا ان العر اق رفض طلب الثركات باللجوء إلى التحكيم بعد صدور قانون رقم (80) لسنة 1961 المشار اليه سابقاً (59) العران

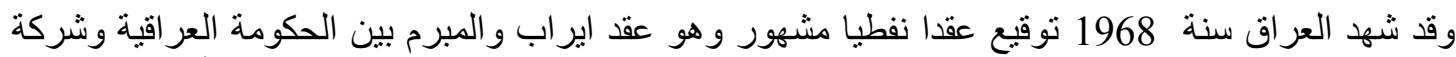

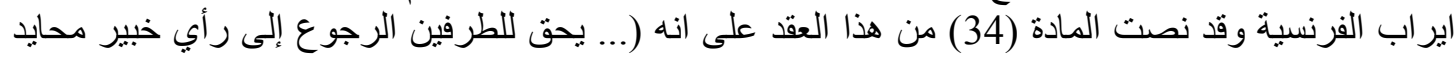

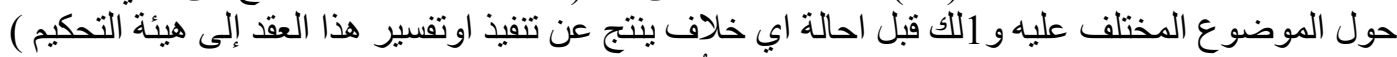

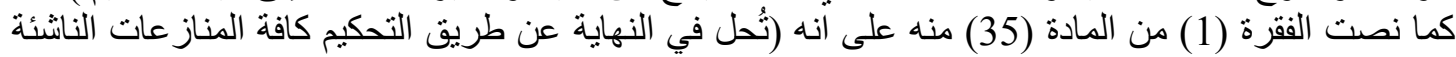

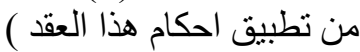
اذن بمقتضى المادة (34) من هذا العقد يتم تقديم استشارة الخبير على التحكيم ولكن بما ان رئ رأي الخبير ليست له له

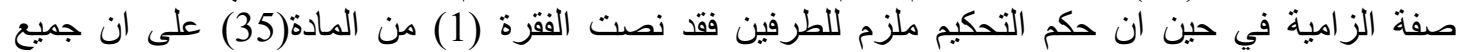

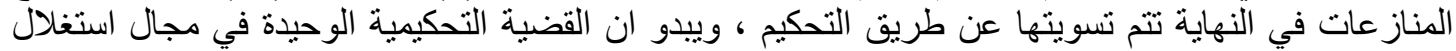

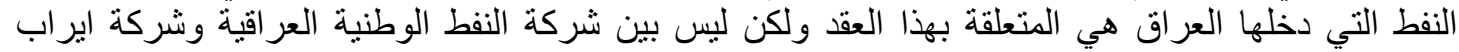

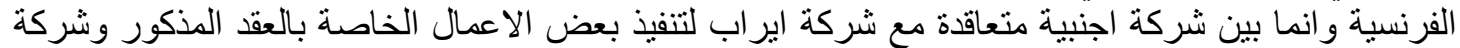

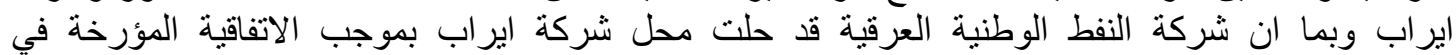

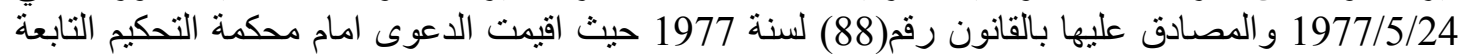

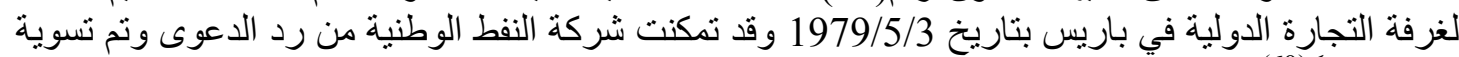

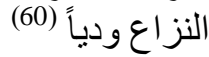
وتجدر الاشارة إلى ان قرارات التحكيم في المنازعات النفطية التي صدرت فيها قرارات تحكيم لايتجاوز عددها

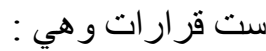
ـ قضية شركة (بتروليوم ) ضد قطر مار ،قر ار اللورد راد كليف بي نيسان سنة 1950.

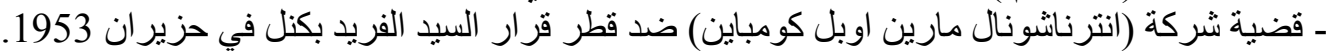

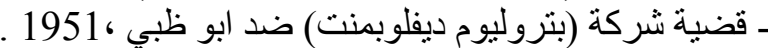

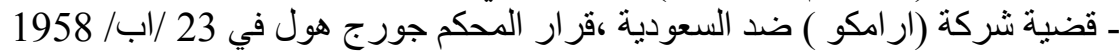

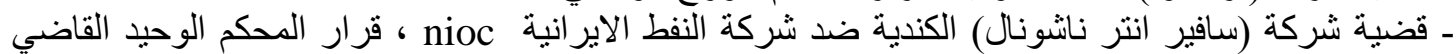

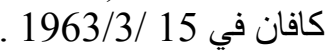
ـ قضية شركتي النفط الامريكيتين (كاليفورنيا ازياتيك وتكساس اوفرسيز) ضد الحكومة الليبية قرار المحكم

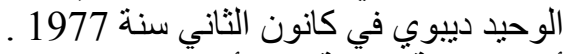

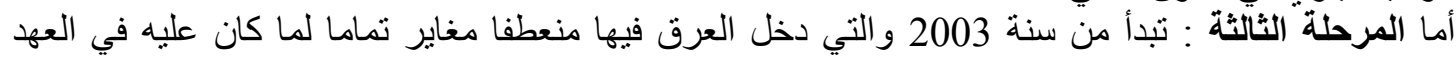

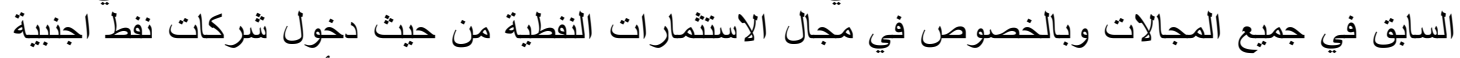

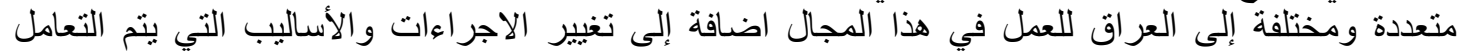

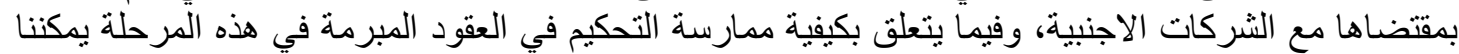

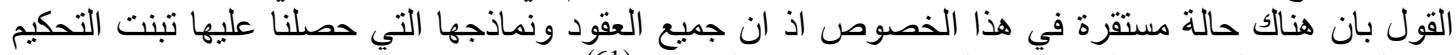

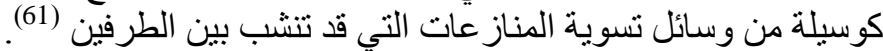

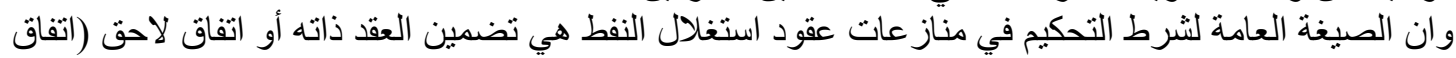

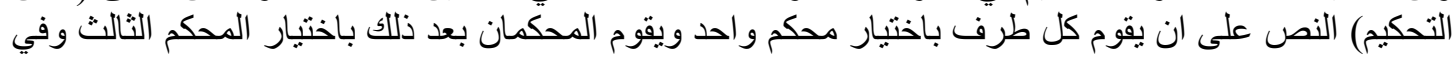




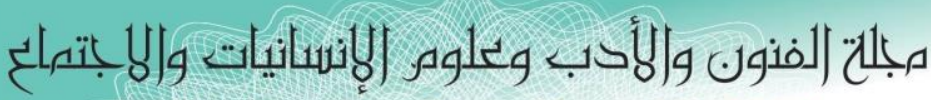
Journal of Arts, Literature, Humanities and Social Sciences

ISSN online: 2414 - 3383

ISSN print: 2616 - 3810

\section{العدد (41) آب - أغسطس 2019}

LALHSS

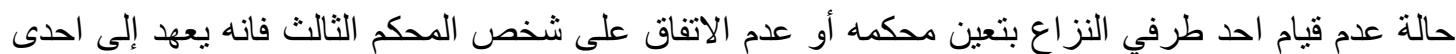

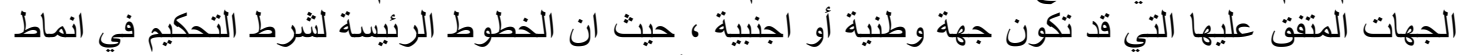

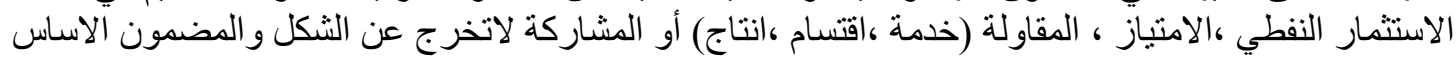

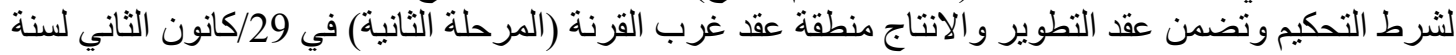

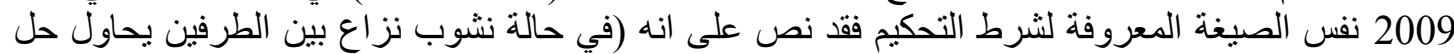

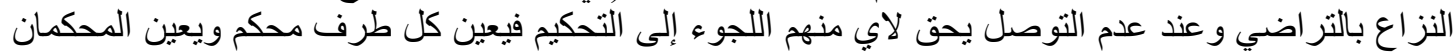

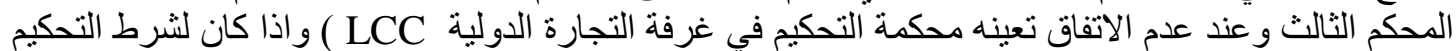

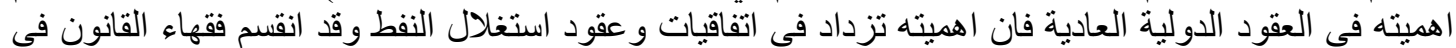

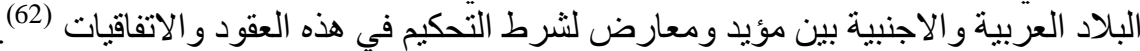

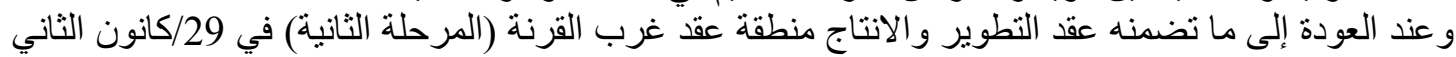
لسنة 2009 و 200

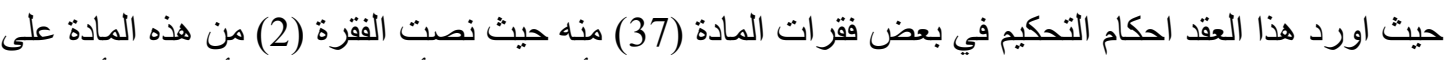

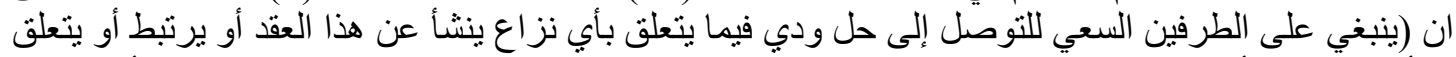

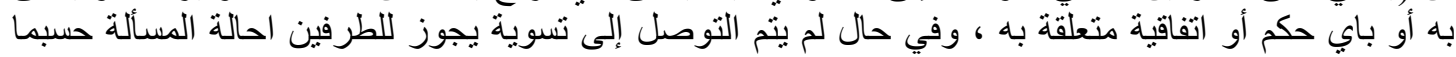

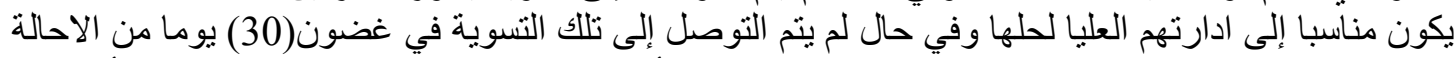

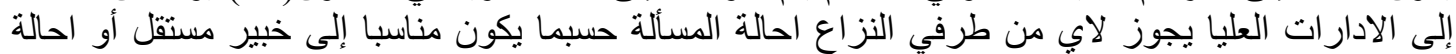

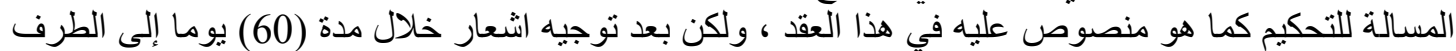

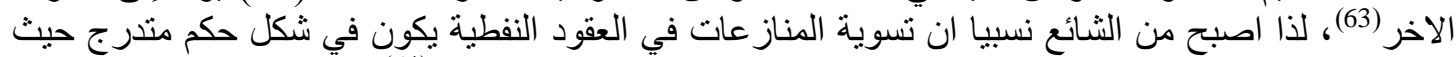

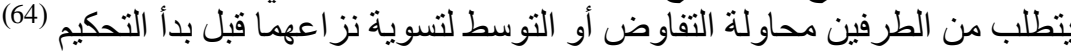

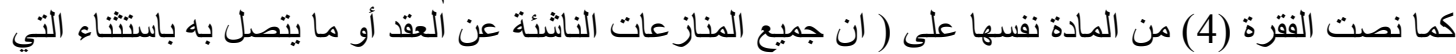

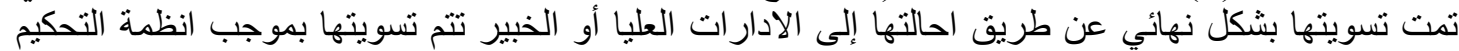

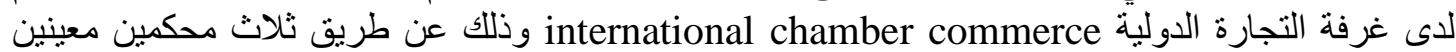

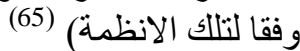
كما نصت الفقرة (5) من المادة نفسها على انه (يكون مركز التحكيم في باريس (فرنسا) الا اذا اتفقا طرفا

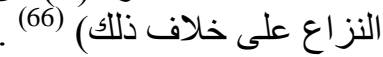

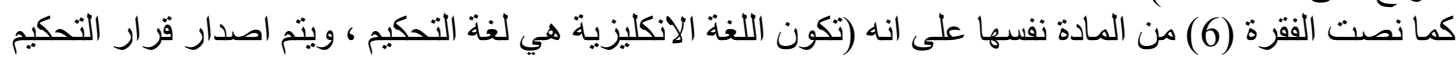

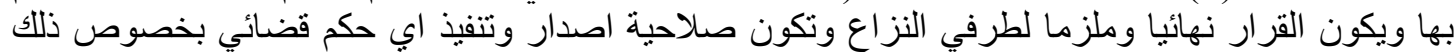

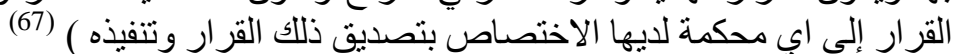

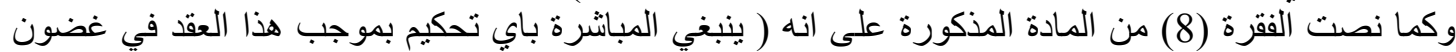

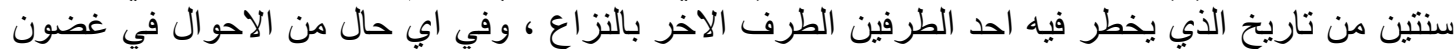
ثلاث سنين من تاريخ انتهاء هذا العقد أو انهائه)(68)

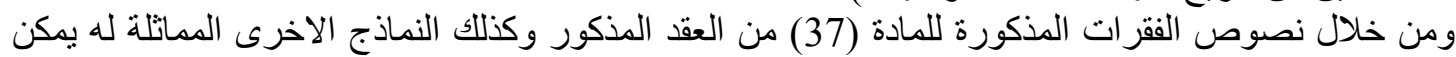

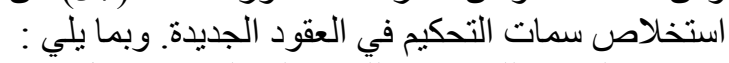

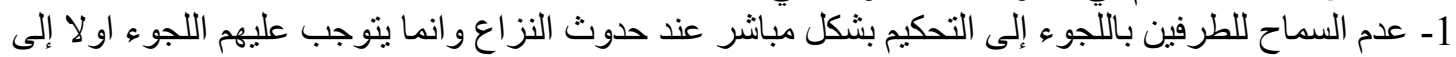

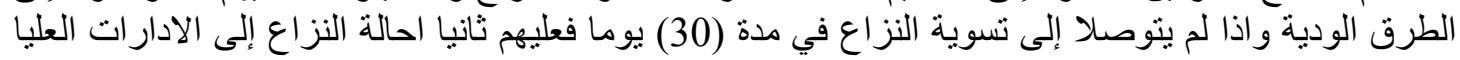

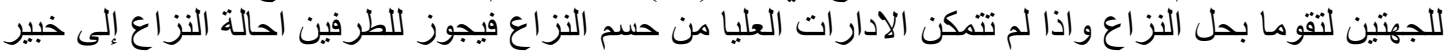

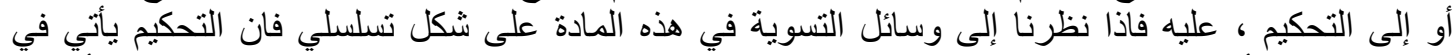

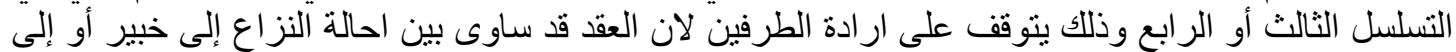

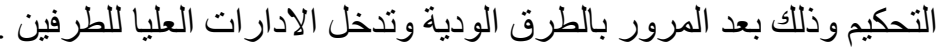

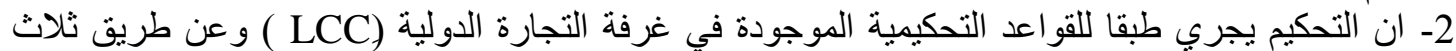

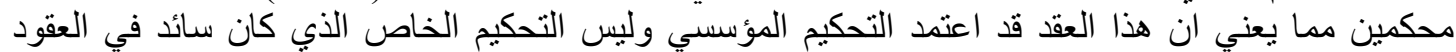


مبلحت (لفنون والأدب وعلوه الإنسانيات والبانتهاع Journal of Arts, Literature, Humanities and Social Sciences

ISSN online: 2414 - 3383

ISSN print: 2616 - 3810

\section{العدد (41) آب - أغسطس 2019}

LALHSS

3- بما ان الفقرة الاولى (2) من المادة (272) من قانون المر افعات المدنية العر اقي ذهبت إلى ان الحكم التئل التحكيمي

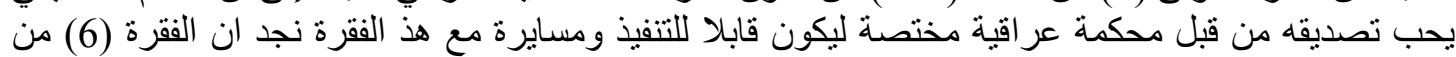

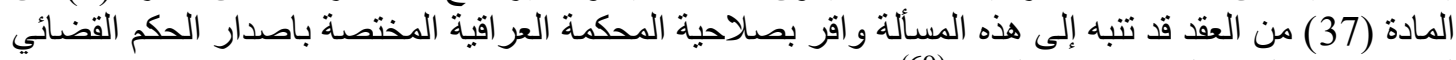

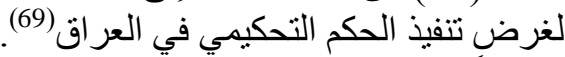

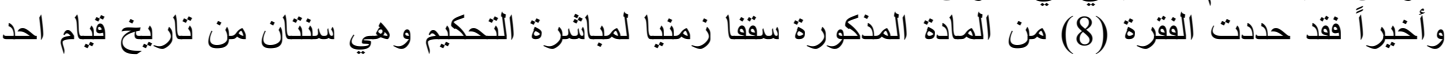

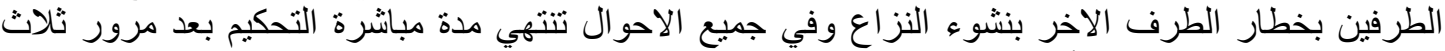

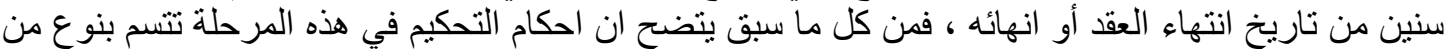
الاستقر ار و الثبات واحتو ائها على تفصيلية قد لانجدها في العقود السابقة كما في تحديد مدة زمنية لمبانشرة التحكيم

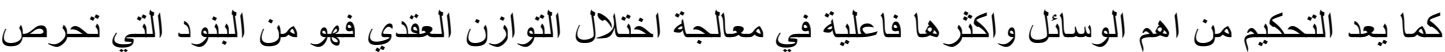

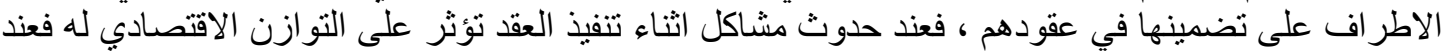

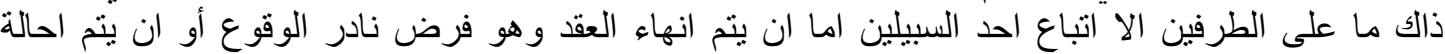

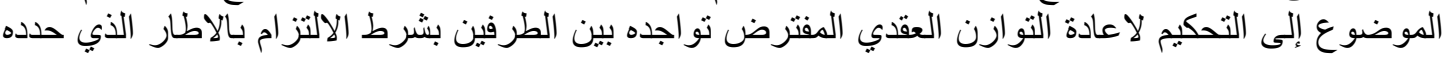

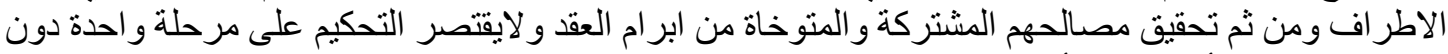

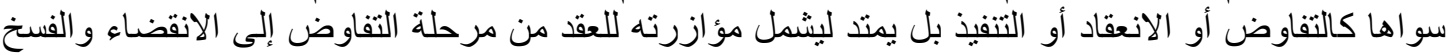

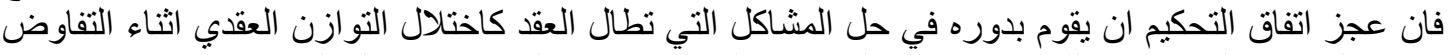

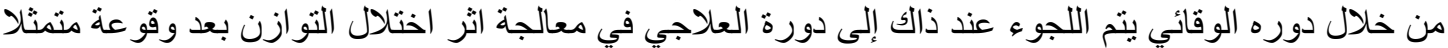

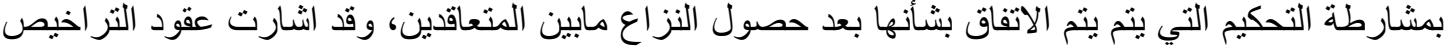

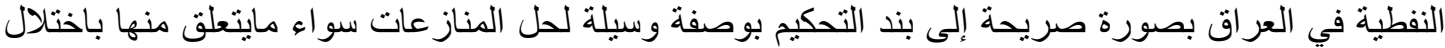

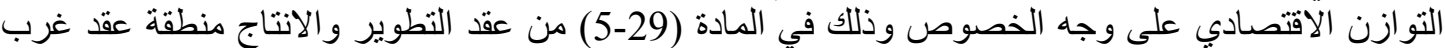

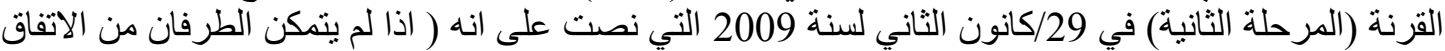

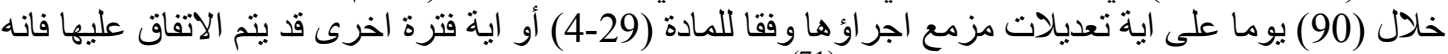
يمكن حل النزاع وفقا للمادة (37) من هذا عزا العقد (71)

الخاتمة

بعد ان انتهينا بعون وتسهيل من الله تعالى من كتابة بحثنا تحت عنوان (التحكيم في تسوية منازعات العقود

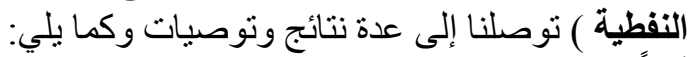

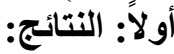

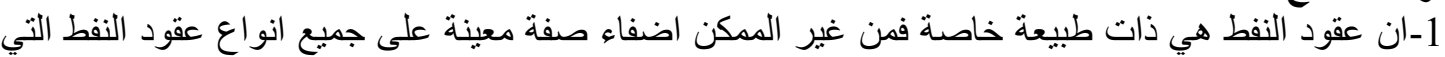

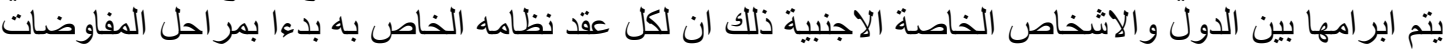

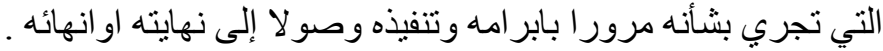

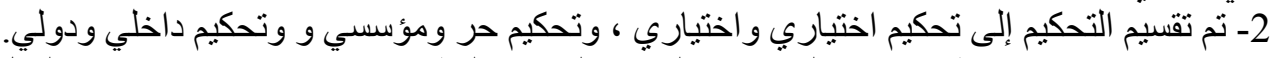

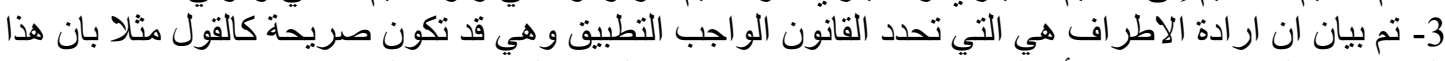

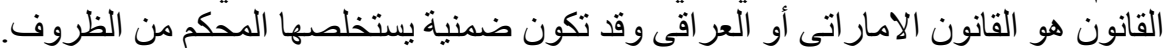

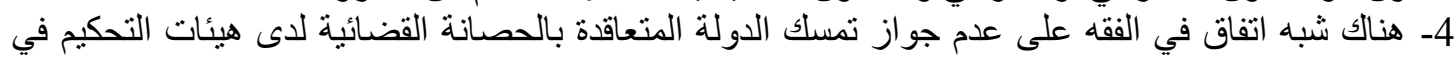

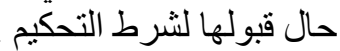
6-تم تقسم ممارسة التحكيم في عقود النفط العربم اقية إلى إلى ثلاث مر احل الاولى (1925-1958) و المرحلة الثانية

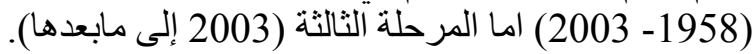
7-تم بيان بانه لايوجد في العراق تنظيم قانوني خاص للتحكية التحكيم في النظام الداخلي وكل مايوجد هو 26 مادة في قانون المر افعات المدنية. 


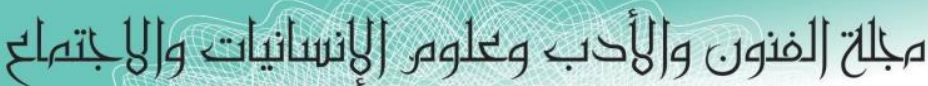

Journal of Arts, Literature, Humanities and Social Sciences

ISSN online: 2414 - 3383

ISSN print: 2616 - 3810

\section{العدد (41) آب - أغسطس 2019}

HALHSS

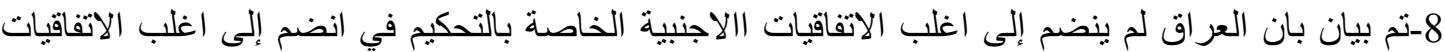

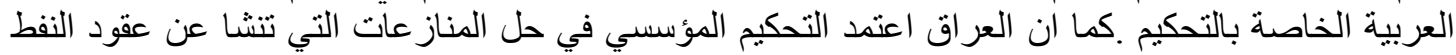
التي ابرمها مع الثركات الاجنبية.

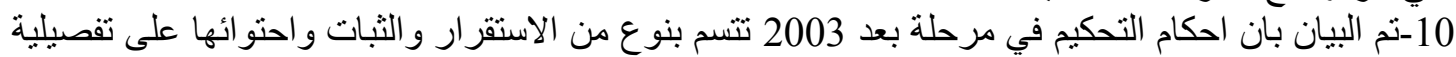

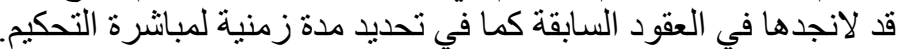

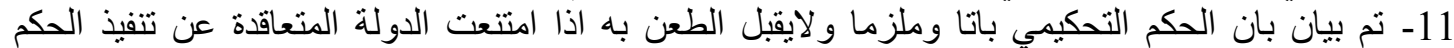

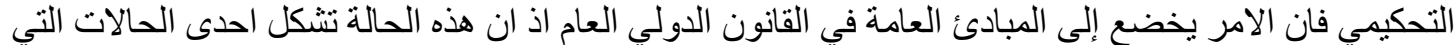

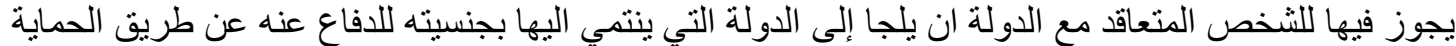

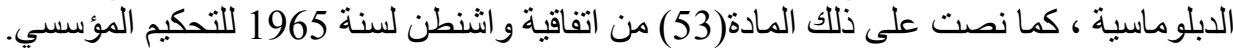

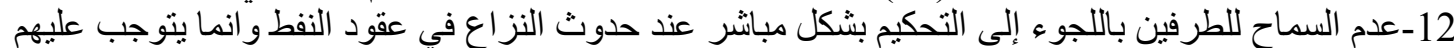

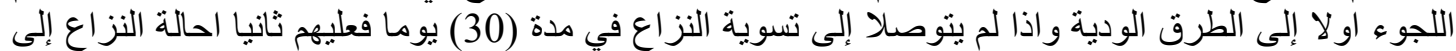

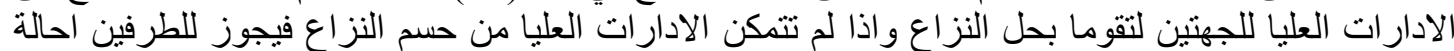
النزاع إع إلى خبير أو إلى التحكين.

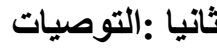

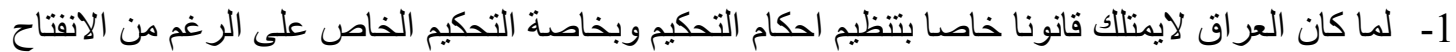

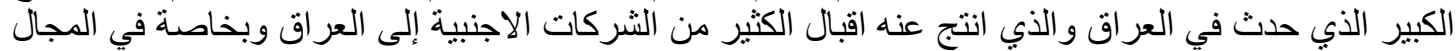

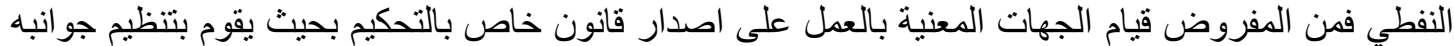

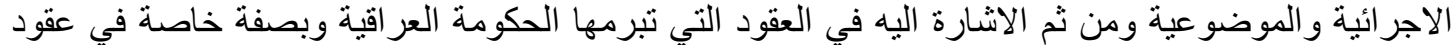

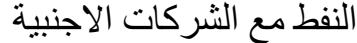

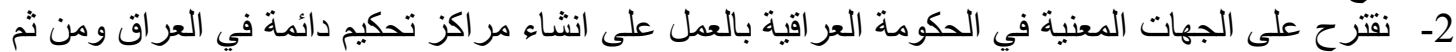

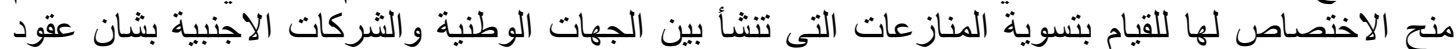

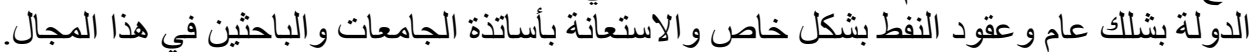

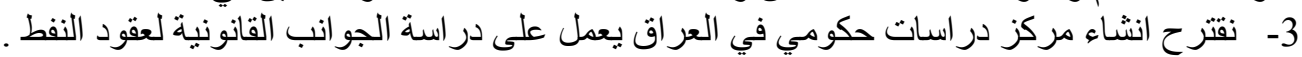

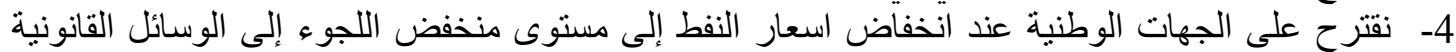

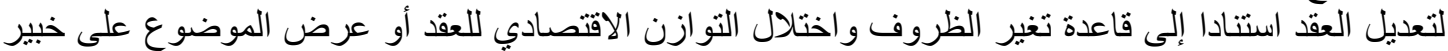

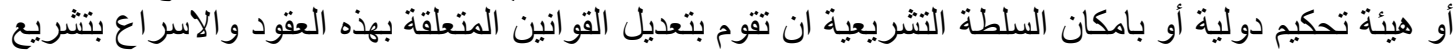

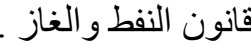

\section{الهو امش}

(1) المواجدة ، مر اد محمود ،التحكيم في عقود الدولة ذات الطابع الدولي ،دار الثقافة للنشر و التوزيع ، الطبعة الاولى ،

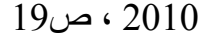

(2) حسن ، محمود نوري ، التحكيم في تسوية منازعات العقود الادارية الدولية ،دار الجامعة الجديدة للنشر، 2017 ،

(3) الاسعد، بشار محمد، الفعالية الدولية للتحكيم في مناز عات عقود الاستثمار الدولية ، منشورات الحلبي الحقوقية، الطبعة

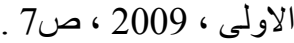

(4) حياوي، نبيل عبد الرحمن، مبادى التحكيم ، المكتبة القانونية للتوزيع، طبعة منقحة ، 2007 ، ص25 ص2

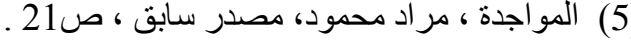

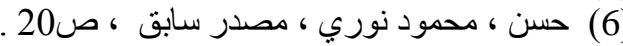

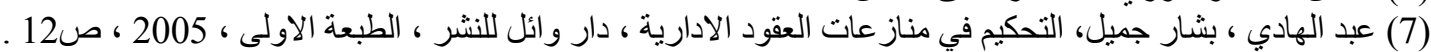

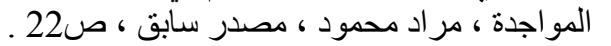




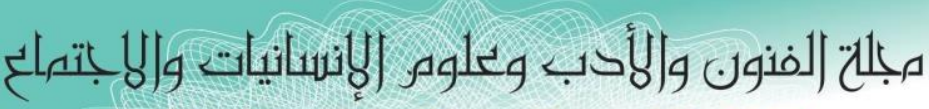

Journal of Arts, Literature, Humanities and Social Sciences

ISSN online: 2414 - 3383

ISSN print: 2616 - 3810

\section{العدد (41) آب - أغسطس 2019}

(9) Diogo pignataro ,international arbitration in the oil and Gas indnstries, universidade federal do rio Grande do norte, brazil,2015 ,P.3, https://www.researchgate.net/publication.

(10) د. جعفر مشيمش ، التحكيم في العقود الادارية والمدنية والتجارية ،منشورات زين الحقوقية ، الطبعة الاولى ،

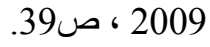

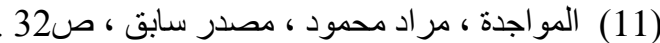

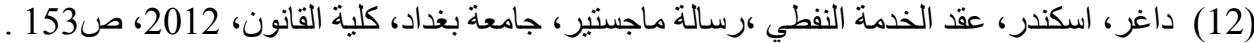

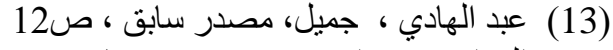

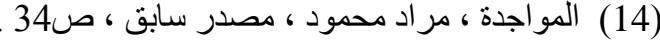

(15) حداد ، حمزة احمد، التحكيم في القو انين العربية ، دار الثقافة للنثر و التوزيع ،الطبعة الاولى ، 2010 ، ص131 صان .

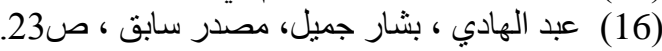

(17) شبيب ، صباح عبد الكاظم ، النظام القانوني لعقد التطوير و الانتاج النفطي في العراق ، رسالة ماجستير ، جامعة

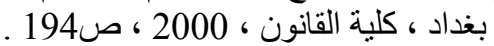

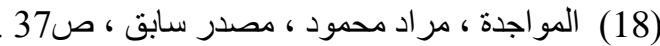

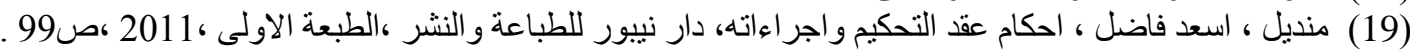

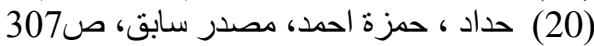

(21) فتاح ، كاوه عمر محمد ميرزا، النفط ومناز عات عقود استغلاله ، رسالة ماجستير، جامعة سانت كليمنتس العالمية ،

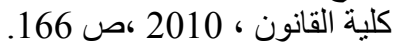

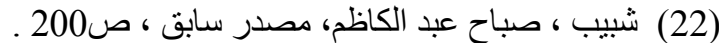

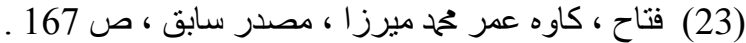

(24) الانباري، علي عبد الرزاق علي ،اثر القانون الثانون الدولي العام في تطور عقود الامتياز ات النفطية ، الطبعة الاولى ، دار

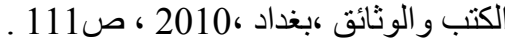

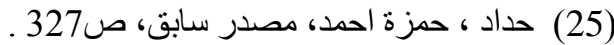

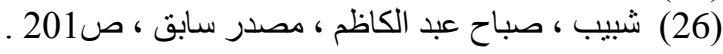

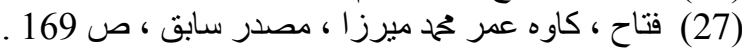

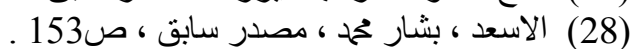

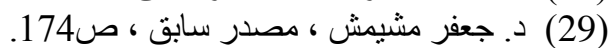

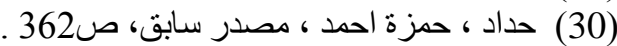

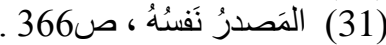

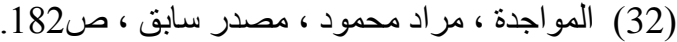

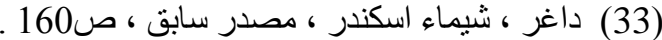

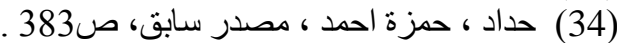

(35) العنزي ، ممدوح عبد العزيز ، بطلان القرار التحكيمي التجاري الدولي ، منشورات الحلبي الحقوقية ، الطبعة

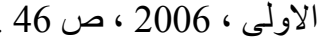

(36) juan Agustin lentini, Arbitration of International Oil, Gas, and Energy Disputes in Latin America, Colorado,2007,p-603.

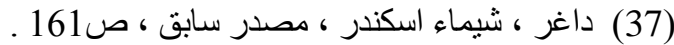

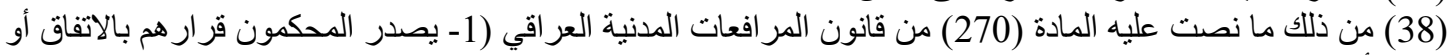

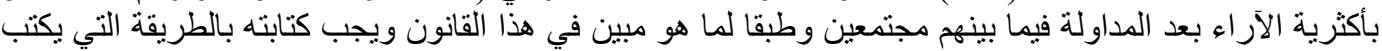

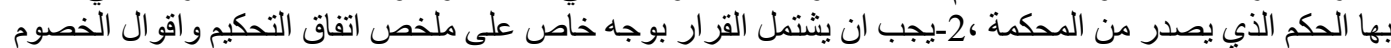

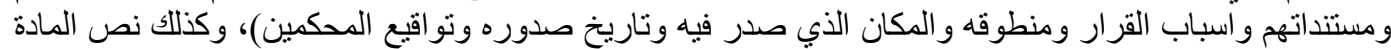

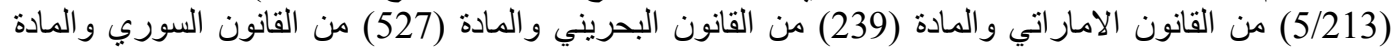

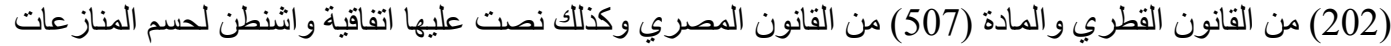

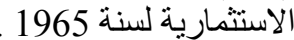

3 شبيب ، صباح عبد الكاظم ، مصدر سابق ، ص205 . 


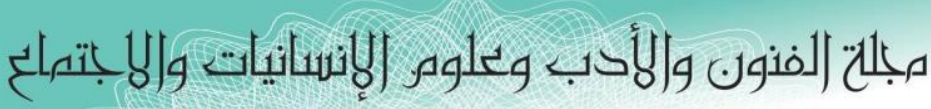

Journal of Arts, Literature, Humanities and Social Sciences

ISSN online: 2414 - 3383

ISSN print: 2616 - 3810

\section{العدد (41) آب - أغسطس 2019}

(40) حداد ، حمزة احمد ، مصدر سابق، ص505.

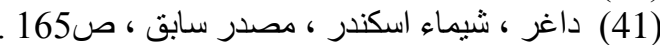

(42) قادر ، ظاهر مجيد ، الاختصاص التشريعي و القضائي في العقود النفطية ، منشور ات زين الحقوقية ، الطبعة الاولى

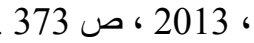

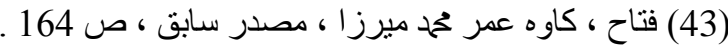

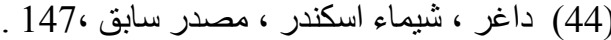

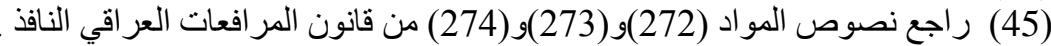

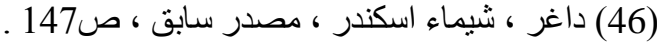

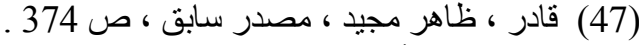

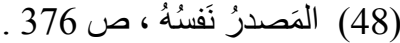

(49) انضم العراق إلى هذه الاتفاقية بموجب القانون رقم (110) لسنة 1983 ،منشور في الوقائع العراقية رقم (2966)

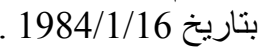

(50) تمت المصادقة عليها بالقانون رقم (104) لسنة 1973 ، منشور في الوقائع العر اقية ، العدد (2278) ،لسنة 1973

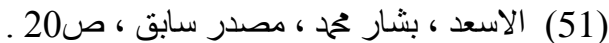

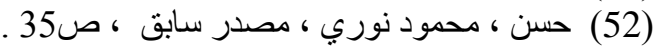

(57) الحداد ، حفيظة البيد ،العقود العبرمة بين الدول و الاشخاص الاجنبية ،بدون طبعة ، منشورات الحلبي الحقوقية،

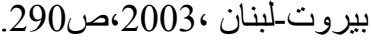

(58) المنايلى ، هاني محمد كامل ،اتفاق التحكيم وعقود الاستثمار النفطي ،الطبعة الاولى ، دار الفكر الجامعي 2014

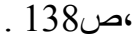

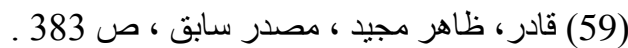

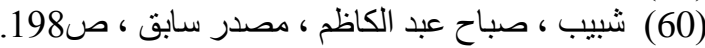

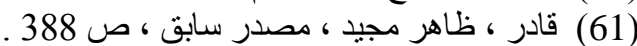

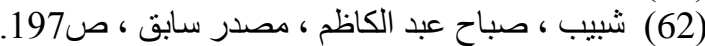

(63) انظر الفقرة الثانية من المادة (37) من عقد الانتاج والنظوير منطقة عقد غرب القرنة ، (المرحلة الثانية) ،في

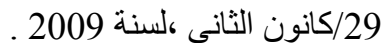

(64) James M. Gaitis , John Burritt Mcarthur, oil \& Gas Arbitration, college of commercial arbitrors,2017,P12. https://www.ccaarbitration.org.

(65) انظر الفقرة الرابعة من المادة (37) من عقد الانتاج والتطوير منطقة عقد غرب القرنة ، (المرحلة الثانية) ،في 2009 29 29

(66) انظر الفقرة الخامسة من المادة (37) من عقد الاتتاج والتطوير منطقة عقد غرب القرنة، (المرحلة الثانية) ،في 2009 20 20

(67) انظر الفقرة ألسادسة من المادة (37) من عقد الانتاج والنطوير منطقة عقد غرب القرنة، (المرحلة الثانية) ،في

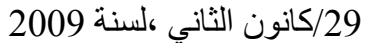

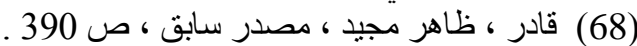

(69) تتص هذه الفقرة على انه (لاينفذ قرار المحكمين لاى دو ائر التنفيذ سواء كان تعيبنهم قضاءً أو اتفاقا مالم تصادق

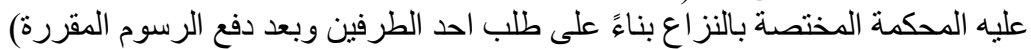

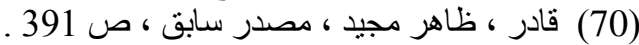

(71) دفار ، سعدية عزيز ، الحق في تعديل عقود التراخيص النفطية في العراق ، اطروحة دكتور اه ، جامعة النهرين ،

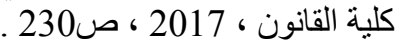




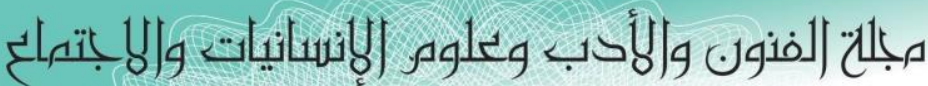

Journal of Arts, Literature, Humanities and Social Sciences

ISSN online: 2414 - 3383

ISSN print: 2616 - 3810

\section{العدد (41) آب - أغسطس 2019}

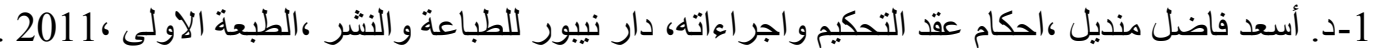

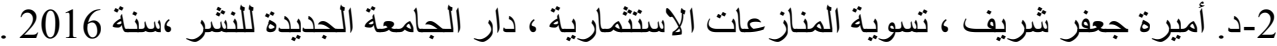

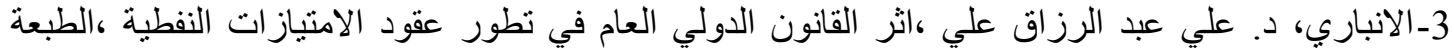

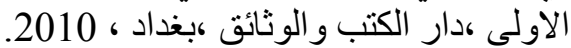

4-د. بشار جميل عبد الهادي ،التحكيم في منازعات ،لئل العقود الادارية ، دار و ائل للنشر ، الطبعة الاولى .سنة 6 2005

5-د. بشار مححد الاسعد ،الفعالية الدولية للتحكيم في مناز عات عقود الاستثمار الدولية ،منشورات الحلبي الحقوقية.

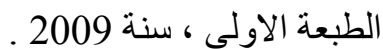

6-د. جعفر مشيمش ، التحكيم في العقود الادارية و المدنية والتجارية ، منشورات زين الحقوقية ، الطبعة الاولى ، سنة 2009 . 2009

7ـ الحداد د. حفيظة السيد ،العقود المبرمة بين الدول و الاشخاص الاجنبية ، بدون طبعة ، منشورات الحلبي

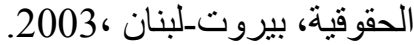

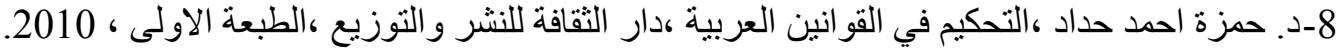

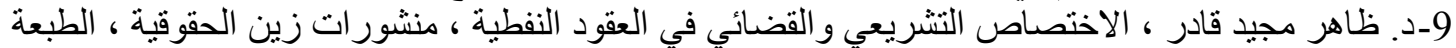

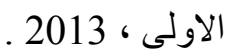

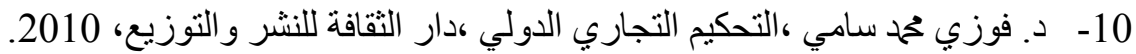

11- محمود نوري حسن ، التحكيم في تسوية منّاز عات العقود الادارية الدولية ، دار الجامعة الجية الجديدة للنشر،

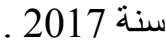

12- د. مر اد محمود المو اجدة ،التحكيم في عقود الدولة ذات الطابع الدولي ،دار الثقافة للنشر والتوزيع ، الطبعة

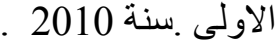

13- د. ممدوح عبد العزيز العنزي ، بطلان القرار التحكيمي التجاري الدولي ، منشورات الحلبي الحقوقية ،

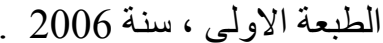
14- المنايلى هاني محمد كامل ،اتفاق التحكيم وعقدد الاستثمار النفطي ، الطبعة الاولى، دار الفكر الجامعي .2014،

15- نبيل عبد الرحمن حياوي ، مبادى التحكيم ، المكتبة القانونية للتوزيع، طبعة منقحة ، سنة 2007.

تانيا : الاطاريح والرسائل الجامعية

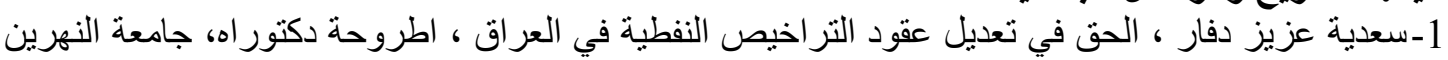

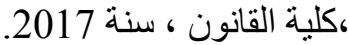

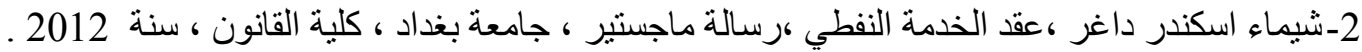

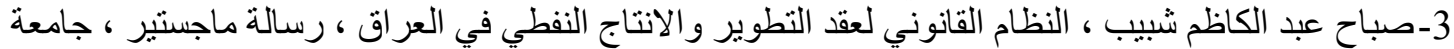

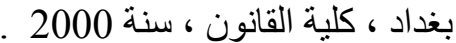
4-كاوه عمر محمد ميرزا فتاح ، النفط ومناز عات عقود استغلاله ، رسالة ماجستير، جامعة سانت كليمنتس العالمية

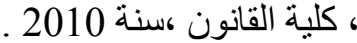

ثُالثا : القوانين

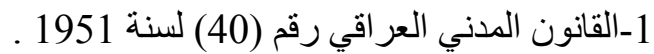
2-قانون المر افعات المدنية رقم(83) لسنة 1969 لـ لسنة 


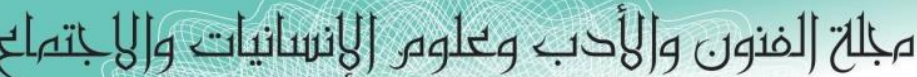

Journal of Arts, Literature, Humanities and Social Sciences

ISSN online: 2414 - 3383

ISSN print: 2616 - 3810

العدد (41) آب - أغسطس 2019

رابع : المصادر الاجنبية:

1- Diogo pignataro ,international arbitration in the oil and Gas indnstries ,universidade federal do rio Grande do norte, https://www.researchgate.net/publication

1- Disputes in Latin America, Colorado,2007.

2- James M.Gaitis ,johnBurritt Mcarthur,oil \&Gas Arbitration,college of commercial arbitrors,2017. https://www.ccaarbitration.org

3- Juan Agustin lentini, Arbitration of International Oil, Gas, and Energy 